\title{
Rethinking the Way of Doing Business: A Reframe of Management Structures for Developing Corporate Sustainability
}

\author{
Thaís Vieira Nunhes ${ }^{1}\left(\mathbb{D}\right.$, Merce Bernardo ${ }^{2}$ and Otávio José de Oliveira ${ }^{1, *}$ \\ 1 School of Engineering, Department of Industrial Engineering, São Paulo State University UNESP, \\ Avenida Dr. Ariberto Pereira da Cunha, 333, Pedregulho, Guaratingueta, Sao Paulo 12516410, Brazil; \\ thais_nunhes@hotmail.com \\ 2 Department of Business, University of Barcelona UB, Av. Diagonal, 690, Barcelona 08034, Spain; \\ merce.bernardo@ub.edu \\ * Correspondence: otaviodeoliveira@uol.com.br
}

Received: 5 November 2019; Accepted: 10 December 2019; Published: 6 February 2020

\begin{abstract}
Corporate sustainability (CS) literature has gone through a period of intense development. The moment is favorable to gather these contributions to consistently advance the state-of-the-art in CS and, also, discuss them in application to real contexts. The main objective of the paper is to systematize, through a literature review using content analysis of the 30 most cited articles from 2007 to 2017, the guiding pillars of CS management. A systematic search for papers was carried out in Scopus and Web of Science, and the initial screening of the papers was assisted by the coding software, MAXQDA 2018, through which the authors structured and analyzed their main insights, contributions, and conclusions. After getting acquainted with the sample, an in-depth reading of the texts was conducted and $60 \mathrm{CS}$ elements were identified. The elements cited in the relevant literature were grouped into six pillars related to corporate sustainability strategy, corporate governance, human resources management, knowledge and innovation management, measurement, disclosure, and independent assurance, and management systems, and integrated management systems. The main contribution of this paper is to identify the management pillars of CS in a systematic way to consistently advance the state-of-the-art in the subject. Also, this study provides understanding to managers on the main aspects that make up the integration of this construct in the companies.
\end{abstract}

Keywords: corporate sustainability; sustainable management; business sustainability; literature review; content analysis

\section{Introduction}

Achieving long-term sustainability is a challenge that requires urgent changes in the way business is done [1]. Companies are interdependent organizations embedded in a global systemic environment that calls for sustainable management of natural, social, and financial resources [2,3]. They are charged for most of the negative impact of economic growth and development because the "price" of extraction, use, and disposal of natural resources for the production of goods is quite significant and impacts not only nature but also society $[4,5]$.

Sustainable management has gained increased attention in the global scenario in light of the unbridled consumerism experienced since the Industrial Revolution when an economy unable to hold the society's economic progress emerged [6,7]. At first, corporate engagement with sustainable development was focused on understanding the meaning of sustainability and its possible implications 
for their businesses. Over time, a growing part of companies began to raise awareness not only about its meaning but also about the need to act effectively on it [8,9].

Indeed, companies have received increasing pressure to be greener from local laws, stakeholders, and final customers, and this has led them to find alternatives to implement sustainability in their operations [6,10]. In 2019, more than 9500 companies in 160 countries signaled their interest in implementing sustainability and having it as an integral part of their business [11].

Corporate sustainability (CS) or business sustainability (BS) is the concept of sustainable development applied to the reality of companies [12]. Whilst sustainable development provides a general view of sustainability, CS has a more suitable and applicable meaning for sustainability in the field of business, management, and operations [7,13]. CS focuses equally on environmental, social and economic performance, which is often operationalized through the triple bottom line (TBL) [14]. The social, economic and environmental dimensions of the TBL are the core of the mainstream sustainability thinking $[15,16]$.

The literature on CS emerged over the 1990s [7,17] and, since then, various terms and definitions have been employed to address this subject; for instance, the definition of sustainable development of the Brundtland report and other CS-related terms such as the abovementioned TBL and BS; the business case for sustainability; environmental and social governance; corporate social commitment; and corporate environmental commitment [13,18-20].

This diversity found in the literature on CS is based on the elaboration of various types of tools and frameworks for CS development. CS deals with the balanced development of economic, environmental and social areas, but to the best of the authors' knowledge, there are no systematic reviews that focus on the joint analysis of aspects that make up the integrated management of these areas. Therefore, considering that the state-of-the-art in CS has gone through a period of intense development since the mid-2000s, it is the moment to gather these contributions to consistently advance the state-of-the-art in CS and discuss how to put them into practice [21].

Based on this, the research question posed in this study is "how can management structures be reframed in order to develop corporate sustainability?" The main objective of the paper is to systematize, through a literature review using content analysis of the 30 most cited articles from 2007 to 2017, the guiding pillars of CS management.

It is expected that this study will identify the management pillars of CS and discuss how they can be developed in order to promote more sustainable businesses. In this study, the pillars are macro elements of management reinterpreted in order to support the integration of CS in companies.

The novelty of the paper is to gather the knowledge created in a framework that can be used as a basis for further studies. This is especially important when a field advances significantly, as in the case of CS. Therefore, the main contribution of this paper is to systematize the generated knowledge (the key elements of the literature, such as the management aspects of CS, the benefits and barriers of implementation) in order to foster future investigations to consistently advance the state-of-the-art in CS. In turn, it contributes towards the dialogue and development of the CS field, especially for management purposes.

The paper begins by first providing an overview of the main aspects of CS management and some information that has inspired the development of this study. This is followed by a discussion of the adopted methodology in Section 3. The results are presented and discussed in Section 4, and, finally, Section 5 provides a summary of findings, concluding remarks, and future research lines.

\section{Theoretical Background on Corporate Sustainability Management}

CS is a strategy of decision-making based on various levels of analysis of social, economic, and environmental issues that act as drivers for aligning a company's business model with its business strategy [14,22]. CS aims to meet the needs of internal stakeholders (employees, shareholders, and managers) and external stakeholders (e.g., customers, suppliers, society, government) without compromising the ability to serve them in the future $[7,12]$. 
The understanding of CS from the TBL perspective was coined in 1990 and popularized by Elkington (1997). It considers environmental, social, and economic aspects having the same value in decision making [23]. By using the TBL, companies can be oriented towards sustainable management, thus including concern with profit, people, and the planet in their culture, strategies, and operations [7,24].

From a holistic perspective, [19] examined factors that promote the adoption of sustainable business practices. The results indicated that the drivers for sustainability in corporations can be internal (related to issues inside the organization) and external (related to stakeholders). Leadership and the business case were found to be the most important internal drivers, and reputation, customer demands/expectations, and regulation/legislation, the external ones.

The adoption of sustainability strategies is attractive from the business point of view, and the results of its implementation, can be pollution prevention, reduction of harmful emissions, and waste minimization [25]; cost reduction resulting from progress on eco-efficiency issues and product innovation [26]; better relationships with regulators and other stakeholders through legal compliance and retention of customers that recognize environmental values [26,27]; and a contribution to fulfilling social needs [28], among others.

The search for obtaining such benefits from a more sustainable performance encompasses risk management and planning from a long-term perspective $[28,29]$. Despite this, there are various barriers and challenges that need to be overcome in order to achieve success with CS practices in the long run $[6,28]$. For example, many companies have failed in planning for short-term horizons, thus blocking potential perspectives for long-term changes $[6,28]$. Further, CS implementation demands a corporate redesign in terms of organizational strategy, objectives and vision that, at first, may not be financially convenient [30].

The focus in initiatives restricted to high-level management, not assuring the commitment of management in making necessary changes throughout their organizational systems, is another critical barrier to implementation [28]. [31] warns about the challenge of managing sustainability trade-offs, which may involve, for example, tensions between short-term corporate orientation versus long-term orientation, the adoption of structural and technological changes versus maintenance of existing practices, and the institution of personal versus organizational sustainability agendas.

Adopting sustainability within a company goes beyond a mere marketing work [28]. It requires the development of organizational commitment, capacity for identification and management of risks and review, and the dissemination of the results achieved to gain stakeholder confidence [6]. Companies engaged with sustainability present an organizational culture focused on sustainability; top management support; stakeholder involvement; environmental training; monitoring of supplier sustainability issues; business evaluation of non-financial parameters, such as quality, internal, and external reputation; and a high degree of commitment to stakeholders [32,33].

CS is implemented in making use of skills and instruments that introduce and develop a sense of collaboration and innovation for sustainability at a level that transcends the limits of a company's direct control [14,24]. For instance, some skills needed are the ability to identify where and how to implement changes and the flexibility for changing behaviors through training rather than simply enhancing technical skills [6]. With regard to the use of instruments for managing internal and external aspects of the TBL, one can highlight, for example, the ISO 14,001 environmental management system [6], the ISO 26,000 corporate social responsibility standard [34], GRI and other CS guidance documents [6], and frameworks for identifying, implementing, and controlling sustainability aspects based on a TBL integrated view [35].

Management system standards and/or guidelines are tools for managing various issues of the social, environmental, and economic pillars of sustainability, such as quality management, corporate governance structures, human capital management, stakeholder relations, environmental protection, and corporate social responsibility [36,37]. Amongst these standards are ISO 9001 (economic 
dimension) [13,15], the ISO 1400 series and EMAS (environmental dimension) [13,38,39], and ISO 26000, SA8000, OHSAS 18,001 and AA1000 (social dimension) [7,13,39].

Although a number of standards related to the management of the three dimensions of sustainable development exist (like those mentioned above) in a compartmentalized form [40], there is still a need for developing a specific standard for implementing sustainability that integrates the environmental, social and economic criteria [41]. The Global Reporting Initiative (GRI) has contributed in this sense and published a set of sustainability reporting standards; however, the focus is on reporting and not on managing CS $[5,19]$. This tool has been also used to measure sustainable performance $[5,8,12,19,27]$.

Also, many other initiatives, indices, and standards have been developed worldwide to develop and report sustainability with greater consistency and transparency [13], such as British Standard BS 8900-1 (guidance) and BS 8900-2 (requirements) for managing sustainable development, World Business Council for Sustainable Development (WBCSD), Sustainability Integrated Guidelines for Management (SIGMA Project), United Nations Global Compact (UNGC) [5,6,13], KLD, EIRIS and the Dow Jones Sustainability Index (DJSI) [5,13].

The measurement of sustainability performance in a business context is an important part of the process of developing sustainable practices [8]. Although companies have made substantial efforts to measure elements of sustainability [28], this question is still not clear for many managers who have asked what they can do in order to improve sustainability performance [27].

The CS field is in constant development, and, according to the existing research [2,21], this field has been open to accepting discussions on its most varied aspects. As pointed out in the introduction section of this study, over the years, several definitions and interpretations regarding CS have emerged [21,29], some with joint emphasis on the environmental and social pillars and others focused on only one of them [21].

A recurring confusion is made, for example, by differentiating the terms CS and CSR. Historically CSR has mostly covered social sustainability issues [42,43]; however, from the second half of the 2000s onwards, the boundaries of CSR have expanded and the term has become a synonym of CS, i.e., the balanced development of economic, social, and environmental responsibilities in companies [42]. However, to date, slightly different references are made to both terms, which often leads to uncertainty [44]. Thus, in order not to create confusion, throughout this paper only the term "corporate sustainability" is used.

Despite the divergences, the vast majority of the approaches to advance CS research refers to the definition of sustainability provided in the Brundtland Report (1987) and/or encompasses the balanced and holistic management of the economic, social, and environmental pillars of TBL [36,45]. The WCED's sustainability definition can be helpful to base organizational strategies to tackle environmental and social sustainability criteria [46]. The TBL has attracted increasing numbers of users as it is a practical tool that uses simple and direct images and narratives to approach and develop the theoretical paradigm of sustainability in the corporate scenario [47].

However, the fact that many studies have been based on these approaches does not leave them immune from criticism. The Brundtland Commission definition and the TBL are useful but do not get companies very far as the WCED's sustainability definition is perceived to be too vague and philosophical [21,48], and TBL implies difficulties in measuring non-financial impacts [47].

Literature reviews are the main path to organize and consolidate the scientific knowledge generated in a given period of time. Over the past four years (2015-2018), the annual number of literature reviews on CS has doubled over previous years (Scopus 2018), which corroborates that researchers have sought to advance the topic by amalgamating and comparing existing findings rather than just proposing new paths without looking at what has already been done. Table 1 shows the literature reviews in CS published between 2015 and 2018. 
Table 1. Literature reviews in CS published between 2015 and 2018.

\begin{tabular}{ll}
\hline \multicolumn{1}{c}{ Research Topic } & \multicolumn{1}{c}{ Author(s)/Year } \\
\hline Corporate sustainability performance & {$[49-54]$} \\
Corporate sustainability and strategic management & {$[36,55,56]$} \\
Sustainable business models & {$[54,57]$} \\
Corporate sustainability reporting & {$[13,30,58,59]$} \\
Corporate sustainability frameworks, tools, and practices & {$[60-69]$} \\
Sustainable supply chain & {$[70]$} \\
Environmental corporate sustainability & {$[71,72]$} \\
Adopting corporate sustainability in specific countries/regions & {$[73,74]$} \\
\hline
\end{tabular}

Table 1 presents the literature reviews in CS grouped in seven key areas of research. These literature reviews are fundamentally important to advance the state-of-the-art in CS; however, they have a specific focus on certain areas of CS research. It can be seen, therefore, that until the moment of the development of this study, no literature reviews have been published as the one proposed on this paper which aims to systematize the guiding pillars for the management of CS.

\section{Research Method}

In this section, the step-by-step of the development of the study is described following the research flow presented in Figure 1. Each of these steps is explained.

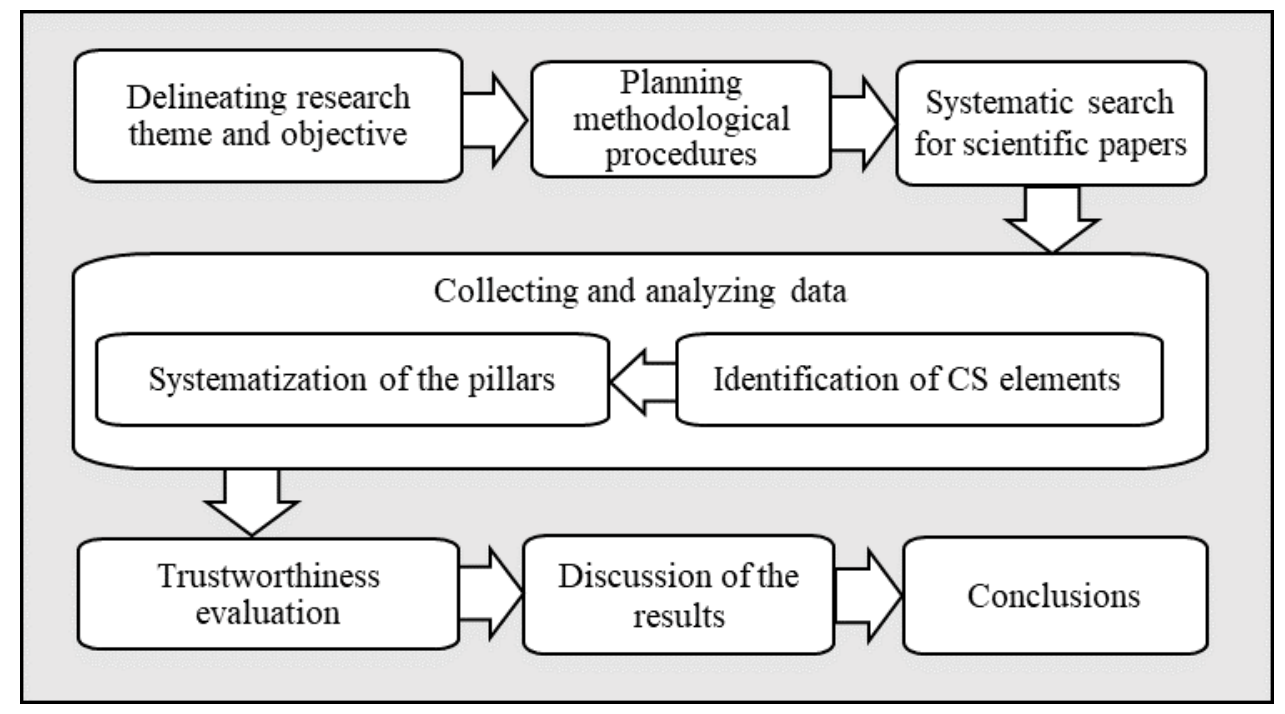

Figure 1. Methodological flow.

\subsection{Delineating Research Theme and Objective}

The planning stage consisted of defining the research theme and objective, which are essential elements to initiate the development of any study. The assessment of the current state-of-the-art in CS before defining the theme and objective of the paper was an important step that allowed us to identify the relevance of developing this research (see Table 1); the review allowed us to define the theme and objectives in order to fill the gap identified. The literature review conducted specifically to identify the research gaps that justify this study included articles published in the last three years (2015-2018) in relevant English-speaking peer-reviewed scientific journals.

The articles that were used to support the novelty of this study were specifically those presented in Table 1 (Section 2) because they are recently published review articles in CS that have different purposes from this study. Therefore, the novelty of this paper is characterized considering the relevance 
of theme under investigation and that up to now, no study presenting an analysis of the literature, as proposed in this paper, was identified. The discussions about the scientific importance of this work can be found in the previous sections.

Based on this assessment of the state-of-the-art in CS, the need to systematize the generated knowledge in the field of CS in order to assist new investigations and consistently advance the state-of-the-art in CS was identified. Thus, the main objective of the paper is defined as to systematize, through a literature review using content analysis of the 30 most cited articles from 2007 to 2017, the guiding pillars of CS management.

\subsection{Planning Methodological Procedures}

After defining the research theme and objective, we planned the methodological procedures to perform the study. It included defining the research method and the steps for its proper execution. Content analysis is a research method that aims to condense the volume of information collected, interpreting the results obtained, and verifying their reliability [75,76]. It can be used to analyze documents published in peer-reviewed journals, being, in this case, a powerful tool for developing literature reviews $[14,77,78]$. The content analysis may be descriptive or exploratory, which use deductive and inductive reasoning, respectively $[75,76]$.

Based on this, we developed a theoretical study through an inductive content analysis of the literature. The content analysis method was chosen because it allowed us to reach the main objective of the study (systematizing CS management pillars), starting from a fragmented state-of-the-art.

The inductive approach was the most appropriate for this work because the categories were created during the process of analyzing the data collected [75].

The planning stage to perform the content analysis followed the recommendations of [76], which suggests, beyond the definition of the objective, the definition of the sample and the unit of analysis, the method of data collection, the method of data analysis, and study implications. Therefore, the objective of conducting the content analysis is introduced in this topic, the definition of the sample and the unit of analysis is presented in Section 3.2, the method of data collection is described in Section 3.3, the method of data analysis is presented in Section 3.4, and finally, the study implications are drawn in Section 3.5.

\subsection{Systematic Search for Scientific Papers}

In order to make the execution of the study feasible, the content analysis was performed with a sample of the 30 most-cited peer-reviewed scientific journal papers. This criterion aimed to select the articles that disseminated the most the knowledge in the literature on CS during the period analyzed, that is, that have supported several other studies that have significantly contributed to advance the state-of-the-art in this field.

Reference [76] points out that sample size may vary according to the objective to be achieved; despite this, it is common that qualitative studies have from 1 to 30 units of analysis. In this study, each article was considered as a unit of analysis (in total 30 units of analysis). Nevertheless, it is acknowledged that this is an unavoidable limitation of the study, which, however, does not compromise the results that were based on the articles that spread the most their contributions in the literature on CS.

The systematic search for papers was carried out on 14 March 2018 in two major research platforms: Scopus and Web of Science. These are the largest databases of peer-reviewed literature and have available titles that go through a rigorous review process that places them among the most reputed journal indexing services $[79,80]$. Scopus and Web of Science were chosen to conduct the search for scientific articles because they are interdisciplinary databases that cover all areas related to management and corporate sustainability. Further, both of them provide access to multiple databases, gathering articles from various journals, and increasing their visibility through the use of a metadata architecture that connects peer-reviewed research of high quality. The use of these platforms is particularly relevant 
for this study because they include the major publishers related to the CS field, for instance, Springer, Wiley Blackwell, Taylor \& Francis, IEEE, American Physical Science, and Elsevier [80].

The keywords used in the research platforms were "corporate sustainability" OR "business sustainability" to be found only in the titles. Other filters used were the period of publication (from 2007 to 2017-a 10-year period of significant development in the field), type of document (articles or reviews), and language (English). After applying these filters, we excluded duplicate articles (present in both Scopus and WOS) and articles that, according to the authors' screening, were outside the scope of the study. Lastly, the search results were ranked in descending order of citation. The final list of 30 papers selected for analysis is presented in Appendix A.

\subsection{Collecting and Analyzing Data}

Reference [81] advises that data collection in inductive content analysis should be opened and performed in an unstructured way. Reference [76] corroborates and further suggests the codification of the data. Based on these recommendations and in line with the chosen method, the list of codes was generated deductively, that is, the elements identified in the articles (in this case, practices for CS development) were coded in the course of the process through qualitative content analysis of the material.

Therefore, the first purpose of the content analysis was the systematization of CS elements presented in the 30 most-cited articles. The initial screening of the texts was assisted by the coding software, MAXQDA 2018, through which the authors structured and analyzed their main insights, contributions, and conclusions. The authors then conducted an in-depth reading of the texts and identified the CS elements.

The notes resulting from this initial analysis went through several refinement rounds, in which the CS elements were gradually compared and assessed by the authors of the study in order to eliminate redundancies and assure reliable coding results. This dialogue between co-researchers to perform content analysis data was recommended, for instance, by [81]. Appendix B shows the final list of CS elements identified in the literature analyzed following the coding process previously described.

The second purpose of the content analysis was to group the related codes for the formation of the categories. The pillars presented in this paper are based on these categories. The accounting of the frequency of occurrence of the codes in each unit of the sample was the criterion adopted to support the systematization of the pillars, as recommended by $[76,82,83]$. Hence, the most frequent elements based on the articles analyzed [83] led to the systematization of the groups, while the other not-so-frequent elements were clustered to them [82].

A group of elements that appeared in at least $30 \%$ of the articles was observed, while the others were much less frequent. This minimum frequency of $30 \%$ was considered for the classification of the most frequent elements. The counting of the frequency of elements is one of the most used methods to perform content analysis [37,82]. This practice is recommended by several authors, for instance, $[76,82,83]$. However, these authors do not define a minimum frequency that should be used. Instead of this, they recommend that the frequency used as barrier should be defined taking into account the particularities of the content analysis itself; that is, it is the authors' decision to establish a limit that brings together a significant amount of elements that can serve as a basis for the grouping and systematization of principles. The frequency of occurrence of the coded elements in the articles can be found in Appendix B.

In order to allow the open extraction of categories totally based on the data collected, categorizing the data in previously defined themes was avoided. The segmentation toward the pillars was carried out from raw data, since there were no previous studies dealing with the phenomenon and because the state of state-of-art in corporate sustainability management is fragmented [14,37]. The categories (pillars) were proposed from the material under examination [75] and guided by the authors based on their experiences conducting content analysis and their expertise in the subject (corporate sustainability). This approach is based on the systematic content analysis method (inductive). 
The advantage of this is the inclusion of insights throughout the interpretation of the results, as envisioned when performing inductive content analysis [14]. The categorization must generate internally homogeneous and externally heterogeneous categories [76]. Therefore, in this study, no element was classified into two groups simultaneously [77]. The grouping of CS elements was conducted in view of the management areas that could support their development.

\subsection{Trustworthiness Evaluation}

Trustworthiness in qualitative research is often difficult to demonstrate. However, the presented method was designed considering important aspects that contributed to the transparency and reproducibility of the study, such as the systematic selection of the articles and the description of the main stages step-by-step that preceded and comprised the performance of the content analysis $[75,78,81]$.

Codes created inductively may vary as the analysis is conducted due to the existence of different interpretations of constructs [75,76]. For this reason, the coding of the elements was performed repeatedly and adapted throughout the process of content analysis, working on discrepancies of interpretations and, whenever possible, aligning encoders to make the results more reliable. This strategy has been used by several researchers to analyze qualitative data [75].

In addition, the researchers themselves are the most well acquainted with the study and, therefore, the most prepared to understand and analyze the results [81]. Hence, the experience of the authors of this work on the theme and the research method employed was important to ensure the quality of the analysis.

\section{Results}

The results presented and discussed in this section have the objective of answering if it is possible to contribute to state of the art in CS evolving from common bases. In order to achieve this goal, the authors conducted a content analysis of the relevant literature (Appendix A) and summarized in six pillars the wide range of CS management knowledge produced and disseminated in the last ten years (2007-2017).

As presented in the research method, a set of 60 elements for CS development and maintenance, with a minimum of $10 \%$ frequency, was identified in the 30 most-cited articles in CS from 2007 to 2017. These most frequent elements are highlighted in Figure 2.

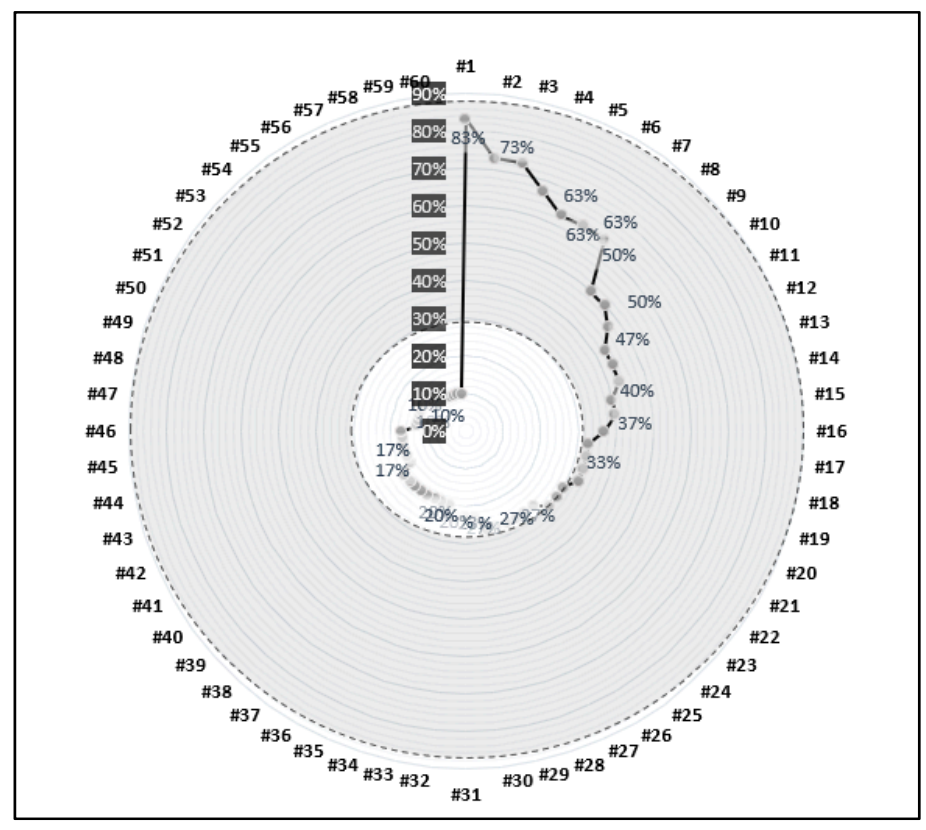

Figure 2. Frequencies of CS elements in the sample. 
Elements with at least 30\% frequency are highlighted in Figure 2. These elements led to the creation of the pillars, while the others were grouped together. Table 2 shows the 60 elements of Appendix A classified according to their frequencies and grouped in view of the management areas supporting their development. Details about the method used in the grouping phase can be found in Section 3.4 of this paper.

Table 2. CS elements and systematization of the management pillars.

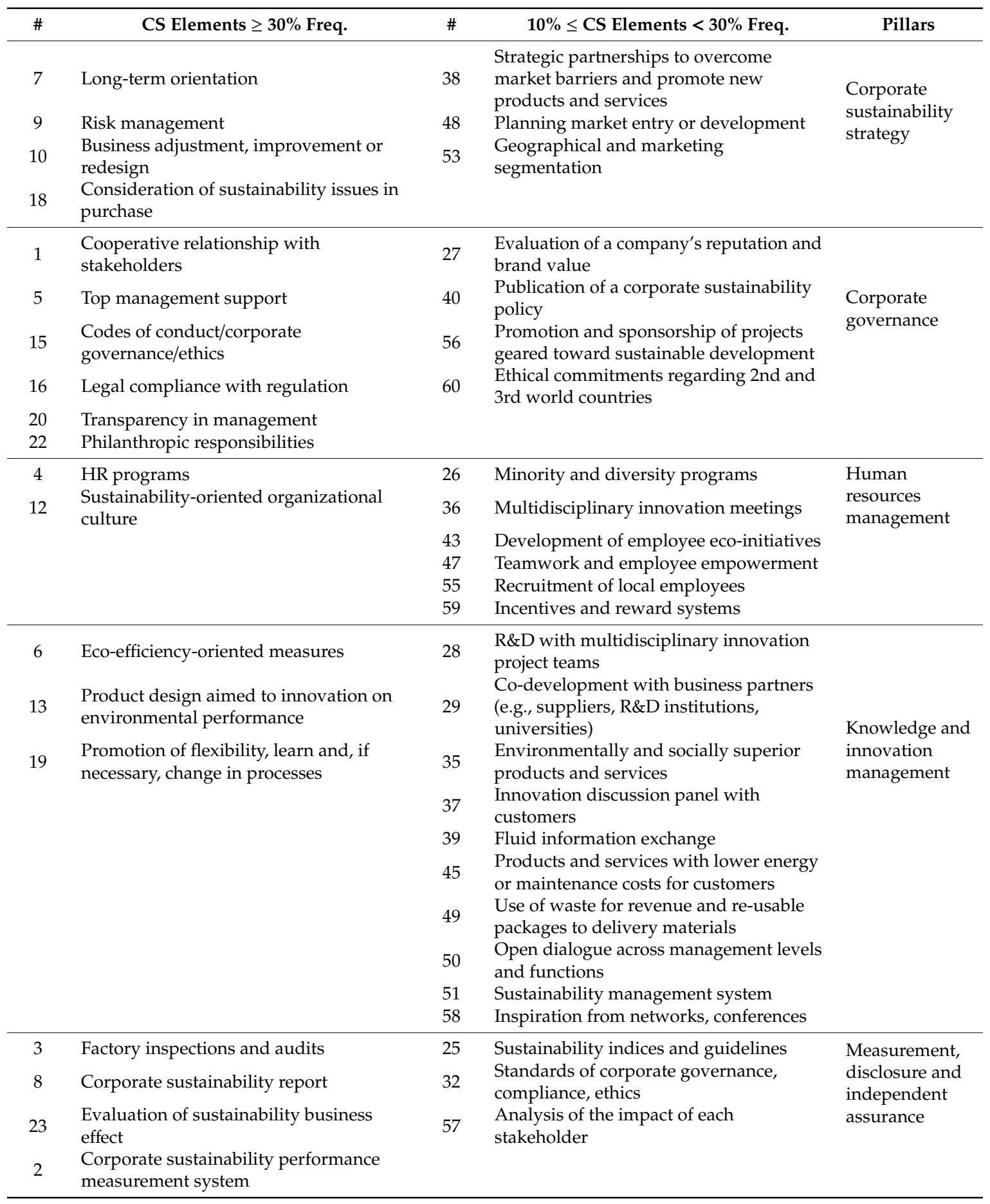


Table 2. Cont.

\begin{tabular}{|c|c|c|c|c|}
\hline$\#$ & CS Elements $\geq 30 \%$ Freq. & \# & $10 \% \leq$ CS Elements $<30 \%$ Freq. & Pillars \\
\hline 11 & $\begin{array}{l}\text { Integration and balance of social, } \\
\text { environmental, and business activities } \\
\text { and responsibilities }\end{array}$ & 24 & Energy and water-saving projects & $\begin{array}{l}\text { Management } \\
\text { systems and } \\
\text { integrated } \\
\text { management } \\
\text { systems }\end{array}$ \\
\hline 14 & Health and safety initiatives & 30 & $\begin{array}{l}\text { Integration of CS with management } \\
\text { systems and/or integrated management } \\
\text { systems }\end{array}$ & \\
\hline \multirow[t]{6}{*}{21} & $\begin{array}{l}\text { Managerial best practices to promote } \\
\text { sustainable supply chain management }\end{array}$ & 31 & Voluntary environmental restoration & \\
\hline & & 33 & $\begin{array}{l}\text { Reduction of the likelihood of } \\
\text { environmental accidents }\end{array}$ & \\
\hline & & 41 & $\begin{array}{l}\text { Reduction of operations in } \\
\text { environmentally sensitive locations }\end{array}$ & \\
\hline & & 42 & $\begin{array}{l}\text { Handling of toxic waste, effluents, used } \\
\text { products from customers, plastic residues, } \\
\text { paper, and others }\end{array}$ & \\
\hline & & 44 & $\begin{array}{l}\text { Occupational health and safety and } \\
\text { human rights standards }\end{array}$ & \\
\hline & & 52 & Sustainability management system & \\
\hline
\end{tabular}

In Table 2, the first left column shows the most frequent elements that led to the creation of the pillars. The second column presents the grouping of the other elements, and, finally, the third column shows the principles derived from the elements in the previous two columns. In this study, the pillars are macro elements of management reinterpreted to enable the integration of CS in the companies.

The elements cited in the relevant literature of the last ten years were grouped into six pillars, namely: corporate sustainability strategy; corporate governance; human resources management; knowledge and innovation management; measurement, disclosure and independent assurance; and management systems and integrated management systems (Figure 3).

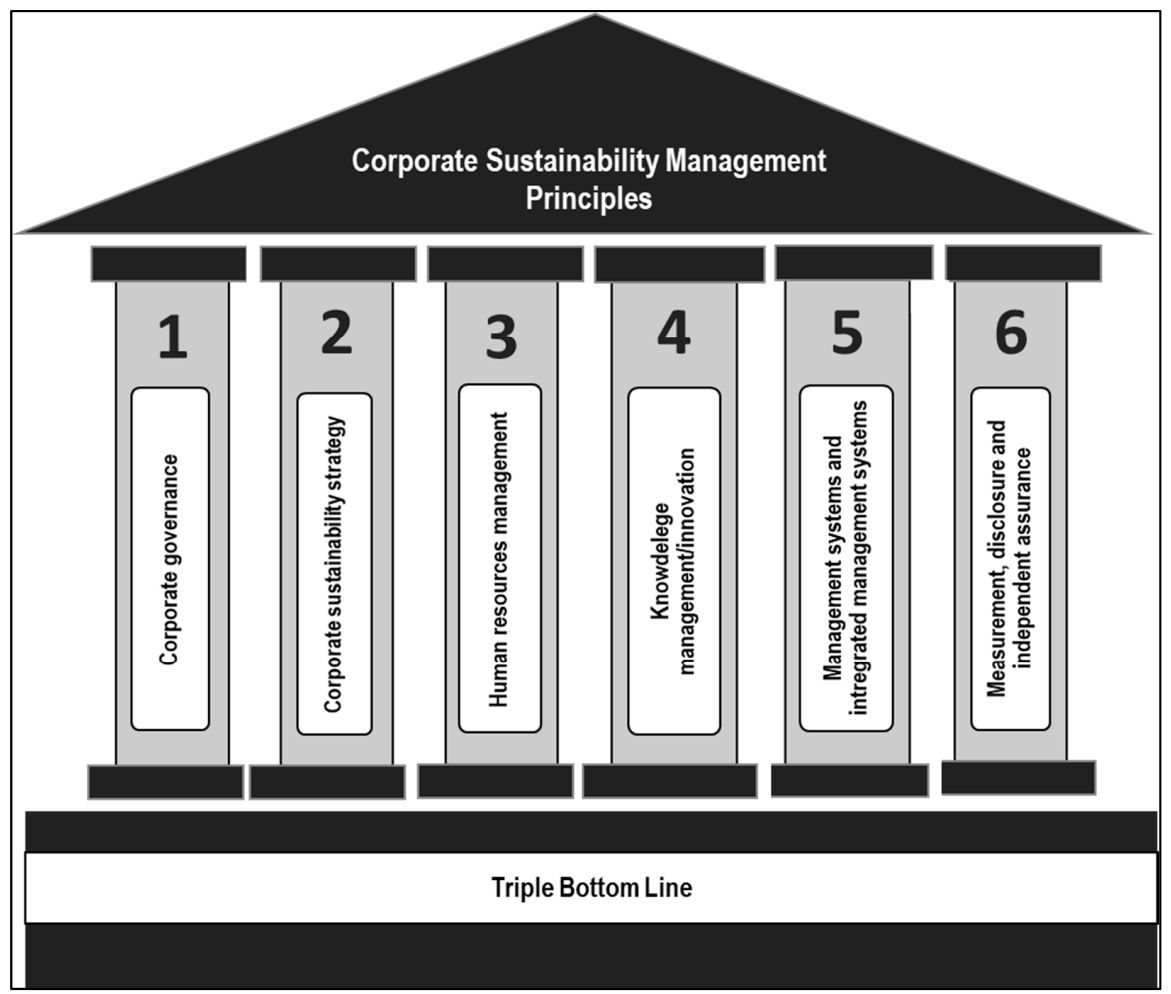

Figure 3. Proposed framework for CS management pillars. 
Derived from Figure 3, it can be observed that all CS management pillars are transversal to the TBL elements. Therefore, it is considered that the elements of the economic, social, and environmental pillars of TBL are embedded in all CS management pillars, which have already been used to develop sustainability both in academia and in companies. This is because the purpose of this work is to contribute with novelty to the advancement of CS theory, using the knowledge consolidated by several authors over the years. Thus, the novelty of this proposal is to create a framework that brings together the best in the literature and those that are already being used in companies with outstanding CS performance.

The six CS management pillars must be developed systematically in order to integrate and balance environmental, social, and economic management at all levels (strategic, tactical, and operational) and environments (internal and external). The pillars are interrelated and the development of each pillar gives mutual support to the development of others, as can be seen in the following sections where they are described. Each of the pillars will be discussed in light of the scientific literature and the authors' experiences. The individual discussion of the pillars may direct researchers in the advancement of the state-of-the-art on specific CS themes and assist managers in developing a management structure that addresses the main elements of sustainability.

\subsection{Sustainable Corporate Governance}

The corporate governance structure plays an important role in the implementation of the sustainability strategy, especially in the face of the scandals and risks of fraud that the corporate world has faced $[33,84]$. Governance is the system according to which the company is directed, monitored, and encouraged, aiming at the existence of a harmonious relationship with its stakeholders [85]. Reliable quality governance enables the creation of a decision-making environment in which transparency, accountability, responsibility, and fairness prevail in all organizational operations and relationships $[35,84,86,87]$. This in itself already contributes to corporate sustainability, but the achievement of social and environmental balance will require the adoption of other CG mechanisms, such as the legal and political system and ownership and board structures [33].

The legal and political system of a company deals with regulations, norms, values, and organizational culture [85]. The values that guide governance may be present in codes of ethics and conduct, which, added to the governance manual, assist the top management in the exercise of its activities $[35,86]$. Governance codes are corporate regulations that guide the board of directors and managers to make decisions that are aligned with organizational goals and strategies $[33,35]$. They are influenced by the determinant mechanisms of CG such as the aforementioned legal and political system and the ownership and board structures [85,88].

The ownership structure represents the concentration or dispersion of ownership among shareholders, which affects the degree of risk diversification, since the greater the concentration of ownership, the more active in corporate decisions and the more risk-averse will the shareholder be. On the other hand, the greater the dispersion of ownership, the greater the pressure from shareholders on managers for business disclosure [85].

As a result, the ownership structure may cause conflicts of interest between the majority and minority shareholders or between shareholders and the board [85]. For this reason, it is considered an important mechanism of CG and, although there is no consensus on its ideal configuration, the transparency in internal corporate control processes from the board structure is considered indispensable for the sustainability of the ownership structure [33]. In any case, it is emphasized that CEOs should maintain harmonious, power-sharing relationships with board members, seeking to avoid narcissistic behaviors that negatively impact the development of corporate sustainability [89].

The board structure can act as a complementary or substitution mechanism to the property structure [90]. Its main objective is to monitor the actions of top management and the way in which internal corporate control is carried out in order to promote corporate citizenship and combat opportunistic management and conflicts of interest, as previously mentioned [85]. For this, the board 
structure must be attended by managers and provide power and incentives to shareholders to participate in the management monitoring work. Other mechanisms can be defined according to the nature of the company, such as the size and independence of the board, compensation management systems, and protection of minority shareholders. [85,91]. It is important that the board evaluate the legal and political system of the company, paying attention to the preservation of ethics, especially in environments with great economic and cultural diversities $[92,93]$.

Governance mechanisms should also promote good corporate citizenship, through which responsibilities and good practices are adopted with investors, customers, suppliers, society, the environment, and regulatory agencies, considering the multiple aspects of the relationship with these stakeholders [94]. This systemic concern with transparent management and the organization's impacts on their stakeholders has a very significant positive impact on sustainability [29,95]. However, the company that aims to develop sustainability in its business should always seek new ways to complement CG mechanisms with actions of socio-environmental balance.

In this sense, the insertion of sustainability issues in a direct and permanent way in decision-making is recommended (pillar 2), e.g., the engagement of the board with social and environmental responsibility and philanthropic actions; the adherence of international management standards and regulations, carrying out internal and external audits/external verifications based on international norms and guidelines such as GRI standards, AA1000 standard on accountability for sustainability, ISAE 3000 international standard on assurance engagements, SA8000 standard on social accountability and ISO 26000 standard on social responsibility [7,13,39]; the disclosure of sustainability results (pillar 5); and the compensation of managers and executives linked to the achievement of socio-environmental objectives (pillar 3) [33,42,86].

\subsection{Corporate Sustainability Strategy}

CS is a strategic issue in the current economic landscape, in which companies are pressured to offer sustainable competitive advantage [18]. With this, environmental and social issues must be considered together with economic issues and included in the company's strategic framework as an important and permanent part of its strategy [18]. The CS strategy, in general, is defined in accordance with the motivations that led the top management to implement sustainability [35]. Therefore, the CS strategy may reveal how economic, social, and environmental issues are approached, and the motivations that led top management to opt for a given type of orientation.

Reference [35] presented, based on a literature review, some reactive and proactive strategies models applied to CS. The introverted model, for example, translates into a reactive strategy aimed in mitigating environmental and social risks, focusing on compliance with applicable laws and regulations. The conservative model is more proactive and aims to achieve eco-efficiency through the development of cleaner production programs. The visionary model involves the development of a proactive and holistic sustainability strategy that encompasses all business activities and provides stakeholders unique, innovative and balanced competitive advantages from the environmental, economic, and social points of view. Identifying and managing risks and opportunities, strengths, and weaknesses related to environmental, social, and economic aspects should be an essential part of the strategic planning of any organization that decides to be committed to sustainability, whether that commitment is strategically reactive or proactive. Risk management will assist in the early assessment of future scenarios and will support the formulation of the long-term CS strategy $[35,96]$.

Long-term orientation is essential for the development of the CS strategy, especially the extroverted sustainable strategy, which seeks to influence the market by focusing on the development of lasting external relationships [35]. CS depends on timeless conscious choices that take into account the mitigation of the economic and socio-environmental impacts generated in the present and the medium and long term [31]. It is, therefore, necessary to adapt, improve and, if necessary, redefine the business model in order to create an environment of mutual trust and cooperation with stakeholders for sustainable development $[33,97]$. Building long-term relationships with stakeholders can result in a 
number of business benefits, such as integrating sustainability across the supply chain, the possibility of market segmentation with access to new customers, expansion operations without incidence of resistance of neighbors, NGOs, or society, among others [32,33,46].

However, the integrated and long-term management of economic, environmental, and social aspects can become a complex task due to the tensions involved in the development of CS. Among the tensions that may hamper sustainable strategic management are technical, financial, market constraints, among other structural constraints that prevent decision-makers from implementing sustainability actions and programs; resistance to meeting demands for more sustainable products and services for fear of loss of legitimacy and risk of institutional disapproval; the difficulty of developing resilience to balance the sustainability pillars among similar companies that operate with homogenized solutions and little diversity to achieve efficiency; and the conflicts between short- and long-term orientations that reflect the paradigm between obtaining financial advantages in the present versus minimizing social and environmental impacts in the future [31].

Faced with so many seemingly contradictory paradoxes and interests, many companies, unfortunately, end up giving up on moving forward with sustainability. It is, therefore, important that these and other potential tensions are recognized and strategically managed in order to advance on the path of sustainability. In this sense, [31] explains that sustainability tensions may vary at different levels, according to the change process and the temporal and spatial context that surround them. Therefore, it is up to the company's top management to define a sustainability strategy that addresses the management of the tensions inherent in its business. All the other pillars of CS management that are discussed below consider important elements that will support the development and implementation of the CS strategy.

\subsection{Sustainable Management of Human Resources}

Human values influence the relationship between employees, which in turn reflects on organizational culture $[32,86]$. Employees that are conscious of the sustainability strategy, satisfied and with stable contracts and permanence, have good production levels and contribute to sustainable development [98]. Human resources management (HRM) plays a key role in achieving this.

Human resources (HR) programs are important means of developing and training employees to work in an environment with an open-minded organizational culture regarding sustainability [19,32,35]. Employees should be gradually integrated into the various sustainability management tools, motivated and made aware of environmental and social objectives and goals, long-term orientation and other strategic aspects of sustainable business development [35,86]. Also, HR should make recruitment efforts to attract sustainability-conscious employees to the company [99]. This is because an alignment of employee values with an organization's values is necessary for mutual motivation to develop corporate sustainability [100].

The recruitment, selection, remuneration, training, and integration practices of the new employees with the organizational culture should be adjusted in order to promote the inclusion of women, black people, people with disabilities since many social groups experience disadvantages with discrimination and prejudice [42,94]. HR in collaboration with top management should establish a positioning on diversity issues, inserting this subject into strategic planning and setting goals and indicators of diversity and inclusion to ensure, for example, equal employment opportunities, the participation of women in the board of directors, the inclusion of people with disabilities and generational balance [12,42,94].

HR management practices are determinant for the management of diversity and minorities, which is an aspect of social sustainability increasingly addressed by companies in the face of legal and regulatory pressures that aim to guarantee human rights and social justice in the work environment $[94,101]$. Therefore, implementing sustainability requires a redirection of the HR function, which must be adjusted to meet the demands of the sustainability strategy defined by the top management [99,102]. 
It is recommended that human resources be managed in an environment of participation and creativity, with an appreciation of teamwork and the development of incentive and rewards programs for employee empowerment. Employees can contribute with ideas and suggestions to improve the organization's social and environmental responsibility [31,32,100]. In addition to these practices, efforts should also be made to strengthen the communication channel with external stakeholders $[35,103]$. In this sense, meetings with partners and suppliers to exchange experiences and technological solutions; voluntary work of employees in the community and lectures and workshops on sustainability for customers and suppliers can be held.

Finally, HRM must be alert to signs of stress, anxiety, worry, and depression that put the mental health of employees at risk. Such symptoms lead to problems that must be managed according to their root cause, that is, by preventing, managing, or trying to alleviate suffering in the workplace [104].

\subsection{Sustainable Knowledge and Innovation Management}

Innovation management has the potential to leverage environmental performance improvements, which, in turn, can improve organizational efficiency as a whole [35]. Investing in technology to reduce the amount of emissions and waste, for example, makes a cost reduction in raw materials and energy possible. Thus, it is suggested that environmental sustainability can complement economic sustainability through knowledge management and innovation, and this investment in green innovation can lead to increased competitiveness in the market, especially in the sustainable business market [33,35].

Innovation management should focus on combining economic gains with the reduction of impacts on the environment and society in the short- and long-term, because after all, not all innovation is sustainable $[35,86]$. The strategy of differentiating products and services should be based on beneficial innovations from the environmental and social points of view, involving, for example, the reduction of energy use in the production process, waste reduction of production inputs, the reuse of waste, the use of reusable packaging for delivery of materials, and the production of goods with lower maintenance costs for customers. For this reason, multidisciplinary R\&D teams should be responsible for maintaining projects of green technology development and co-development with partners (e.g., universities, suppliers, customers) to improve environmental and social performance through redesign and improvement of products, processes, and services [86,94].

The development of CS needs to act as a transforming and innovative force in all the functions of the organization $[35,86]$. However, the implementation of changes resulting from sustainability-oriented innovation management processes requires a flexible and open-minded organization [105]. In this sense, knowledge management $(\mathrm{KM})$ practices can help in the institutionalization of innovative behaviors, products, and processes $[105,106]$. KM practices involve the processes of creation, dissemination, and use of knowledge from sources such as the organization itself, information technology, and collaborators [105,107].

The creation and application of knowledge can improve the communication flow between top management and employees and facilitate the dissemination of the sustainability-oriented organizational culture [108]. In addition, stakeholders have increasingly requesting information about the choices, investments, and actions taken by companies that occupy a prominent position in sustainability in the market [94,95].

The pillar of knowledge management and innovation is essential to respond to this type of pressure because its development will support the availability of information and knowledge in accessible and usable formats to all stakeholders [109]. Specifically, KM processes can support the development of the following pillar "measurement, disclosure and independent assurance", providing tools for managing and providing data and information on social, economic, and environmental issues.

The knowledge management and innovation pillar should focus on the development of sustainability through the creation of a company with digital connectivity that constantly optimizes its operations in a 4.0 industry atmosphere [29]. 


\subsection{Measurement, Disclosure, and Independent Assurance of Corporate Sustainability}

Corporate sustainability performance (CSP) is an important element for the achievement of objectives for sustainable business development, such as those proposed by the Organization for Economic Co-operation and Development (OECD) guidelines for multinational enterprises, the Dow Jones Sustainability Index (DJSI), the United Nations Global Compact (UNCG), the Global Reporting Initiative (GRI) guidelines, and the World Business Council for Sustainable Development (WBCSD) initiatives [94].

CSP aims to monitor and evaluate the incorporation and management of economic, social, and environmental aspects in the company's activities, considering a prior analysis of the impact of these activities on the environment and society $[94,110]$. It is interesting that the company maintain a sustainability performance evaluation system (SPMS) to evaluate the advances or setbacks obtained with the implementation of sustainable practices, also called "sustainability business effect". The SPMS promotes the diagnosis and evaluation of the objectives, goals, and sustainability indicators inherent to the sustainability strategy adopted by the company $[94,111]$. The implementation of an SPMS basically involves three phases, namely, (1) the definition of corporate and sectoral indicators (KPIs), (2) the implementation and use of KPIs and integration in processes and organizational structure, and (3) SPMS improvement [111].

In defining the set of KPIs, it is important to relate the effectiveness of each KPI to the achievement of a particular objective in the TBL areas, or more specifically, with the areas of sustainability performance proposed; for example, by GRI, economic performance, market presence, indirect economic impacts, procurement practices, anti-corruption, anti-competitive behavior (economic pillar), materials, energy, water and effluents, biodiversity, emissions, effluents and waste, environmental compliance, supplier environmental assessment (environmental pillar), employment, labor/management relations, occupational health and safety, training and education, diversity and equal opportunity, non-discrimination, freedom of association and collective bargaining, child labor, forced or compulsory labor, security practices, rights assessment, local communities, supplier social assessment, public policy, customer health and safety, marketing and labeling, customer privacy, and socioeconomic compliance (social pillar) [12,94].

It is also necessary to define optimal numbers of KPIs based on the organization context, to consider the use of composite indexes, and to develop criteria for addressing conflicting objectives [94,111,112]. At this stage, managers responsible for the SPMS may take as a basis the CS KPIs present in guidelines and standards related to sustainability, adapting them to the scope of application $[94,113]$.

In the implementation and use of the indicators phase, it is necessary to consider and manage the existence of failures in the data and information gathering that feed the SPMS, to identify the most impacting indicators in the sustainability performance, and to explore the possibilities of using financial and non-financial indicators in the accountability and disclosure of sustainability information $[94,111]$. The SPMS results should then be used as input in the decision-making process and for the continuous improvement of the SPMS itself. The continuous improvement should involve the re-evaluation and possible re-adaptation or replacement of the indicators [12,92].

Accountability for economic, social, and environmental progress is an increasingly common practice in promoting value creation and communication with stakeholders $[95,114]$. This is developed through the publication of integrated reports, which present financial and sustainability information integrated into a single document with the objective of making public the position of the company with respect to sustainability $[12,114]$. The sustainability report is a channel for communicating with stakeholders through which the company details its strategies, operations and business in the short, medium, and long term [86,114]. Through it, the dialogue with stakeholders is developed by enabling, for instance, that problems and opportunities for improvement be pointed out by the public who have access to the company's sustainability report.

Sustainability reports should be an overview of the company's activities; however, its credibility has been questioned due to the widespread use of biased language and the omission of data and 
negative aspects towards obtaining a positive image in the market [114-116]. Disclosure of information about CS is voluntary in many countries and, therefore, many companies do not follow formal rules or regulations on the form and content of disclosure [116].

For this reason, independent assurance of sustainability reports is recommended in order to assess the quality, comparability, and credibility of information made available to the public [90]. This verification goes beyond traditional accounting and quality audits, also involving external verifications based on international norms and guidelines such as GRI standards, the AA1000 standard on accountability for sustainability, the ISAE 3000 international standard on assurance engagements, the SA8000 standard on social accountability and the ISO 26000 standard on social responsibility $[7,13,39]$. It should be noted that although external verification is recommended, it is not a mandatory requirement of GRI, and the companies wishing to carry it out can self-report this information in their sustainability report.

\subsection{Sustainable Management Systems and Integrated Management Systems}

Management systems (MSs) provide important data and information for evaluating the CSP since the management of much of the economic, social, and environmental issues that the organization has responsibility for are concentrated in them [117]. According to ISO, a management system is "a set of guidelines used to manage the interrelated parts of the business in order to enable the proposed objectives to be achieved" (ISO 2019). Some MSs can be certified and, in this case, they are models based on expert opinions that express by means of guiding and/or mandatory requirements of what organizations can do to implement and maintain a cycle of continuous improvement of operations (ISO 2019). There are several studies that highlight the contribution of MSs to the sustainable development of organizations, mainly relating economic performance with ISO 9001 [118-120]; environmental performance with ISO 14001 and EMAS [94,118,119,121], and social performance with ISO 26000, SA 8000 and OHSAS $18001[94,118,119]$, the latter replaced in 2018 by ISO 45001.

ISO 9001 is a certifiable standard that establishes the requirements of a quality management system and is naturally related to the economic dimension of sustainability [122]. However, ISO 9001 also addresses requirements related to the social dimension, such as responsibility and customer orientation, stakeholder needs analysis, labor practices, training and education, and fair practices of responsible supply chain management and operation [122,123]. Additionally, the 2015 version of ISO 9001 contains requirements related to the development of knowledge management, which, in turn, contributes to the development of CS, as discussed in detail in pillar 4. ISO 14001 has the potential to contribute directly to environmental sustainability because it provides a framework of technical and administrative requirements to develop and maintain a certifiable environmental MS balanced with socioeconomic needs [124]. Some studies also suggest that ISO 14001 positively impacts the economic dimension due to the reduction of costs obtained with improvements in process efficiency and access to new customers due to the projection of a better image into the market [125]. ISO 45001 establishes the requirements of an occupational health and safety MS and contributes to the development of social responsibility. Despite this, in order to contribute more significantly to social sustainability, it is recommended to complement these MSs with the requirements of ISO 26000 (corporate responsibility), SA 8000 (social accountability), and AA1000 (sustainability assurance) [122].

In 2008, Jorgensen already argued that the implementation of MSs and their subsequent integration could strengthen the interrelationship between the different areas of the business, creating a transversal connection for the integration of sustainable best practices [118]. The author also highlighted the importance of extending the focus of MSs to include the management of external relationships along the supply chain, thus contributing to sustainable business development. However, for a long period of time, an integrated management strategy was only considered for ISO 9001 and ISO 14001 standards, sometimes including OHSAS 18001. From 2013 onwards, SA 8000 and AA1000 have also been incorporated more frequently into IMSs with the objective of addressing CSR in business [113]. As suggested by [126], it is observed that more comprehensive IMSs have been gradually developed, 
mainly following the publication of new MS standards by the ISO (International Organization for Standardization) and the ITU (International Telecommunication Union).

According to the ISO, the main motivation for the revision and publication of standards and guidelines comes from the need to provide patterns that are aligned with the real stakeholders' needs and expectations, who are becoming increasingly aware and interested in the positioning of companies with regard to the management of its impact on society and the environment (ISO 2019). This fact explains the increasing number of standards and guidelines dedicated to addressing sustainability issues in different areas and sectors. However, it must be acknowledged that many criticisms are made around the adoption of international standards because sometimes they are implemented due to external pressures and have the sole objective of obtaining certification, with no prospects of achieving real improvements for the sustainability of the business [127,128].

In light of this, [127] argues that the lack of an international certification for IMSs causes integration to be motivated by internal reasons, which positively impacts the performance of the IMS and its integration with the strategy. Therefore, it is suggested that, based on IMS, companies can manage a wide variety of objectives related to key areas of CS, thus contributing to the effectiveness of the CS strategy. In this sense, one aspect to be considered is the definition of the scope of the IMS, identified by [127] as a possible contingent factor in CS performance that needs to be empirically investigated. This assessment of the scope of the IMS is especially relevant because, as previously highlighted, an increasingly broader range of integrable management systems is currently available. In this way, depending on the focus that the MSs present, the IMS could be more or less effective in meeting stakeholders' needs. Table 3 presents some MSs (certifiable and not certifiable) related to the TBL of CS.

Table 3. Management standards, guidelines, and regulations approaching TBL aspects.

\begin{tabular}{ll}
\hline TBL Focus Area(s) & Management Standard/Guideline/Regulation \\
\hline \multirow{3}{*}{ Economic } & - ISO 9001 Quality management system \\
& - ISO 44001 Collaborative business relationship management systems \\
& - ISO 37001 Anti-bribery management system \\
& - ISO 22301 Business continuity management system \\
\hline \multirow{3}{*}{ Environmental } & - ISO 14001 and EMAS-Environmental management system \\
& - ISO/DIS 24526 Water efficiency management systems \\
& - ISO 50001 Energy management system \\
& - ISO 14064 Carbon management system \\
\hline \multirow{3}{*}{ Social } & - ISO 45001 Occupational health and safety management system \\
& - ISO 18788 Management system for private security operations \\
& - SA 8000 Social Accountability \\
\hline \multirow{3}{*}{ Economic, environmental } \\
and social & - ISO 19600 Compliance management system and AA1000AS Assurance standard \\
& - ISO 28001 Security management system for the supply chain \\
& - ISO/IEC 27001 Information security management system and ISO/IEC 2000-1 \\
& - ISO 30401 Human resource management-Knowledge management systems \\
& - ISO 31000 Risk management system \\
& - ISO 26000 Guidance on social responsibility \\
& - British BSI PAS 99; Danish DS 8001; Spanish UNE 66177; Australia/New Zealand \\
& AS/NZS4581 Integrated management system \\
& - BS 8900 Managing sustainable development
\end{tabular}

The MSs shown in Table 3 cover important aspects for the development of CS, which are addressed in the pillars presented in this study. Unfortunately, the relationship of most of these systems to CS has not been sufficiently explored in the literature of IMS [129,130]. Thus, in line with [127,128], the authors of this work suggest that further studies should be conducted in order to understand the use of IMS as a CS developer, especially considering combinations of MSs not studied or studied but not intensively (e.g., ISO/IEC 27001, ISO 22301, ISO 31000, ISO 37001, ISO 50001, AA1000) and their possible contributions to a better integration and performance of CS. 


\section{Conclusions}

This paper aims to systematize the guiding pillars of Corporate Sustainability (CS) management. This objective was achieved through the conduction of a content analysis of the 30 most-cited academic articles on CS from 2007 to 2017. As a result, six pillars for CS management were systematized: sustainable corporate governance; corporate sustainability strategy; sustainable management of human resources; sustainable knowledge and innovation management; measurement, disclosure and independent assurance; and sustainable management systems and integrated management systems.

It is concluded that CS will only have effect once sustainability issues are formally integrated into corporate management structures. This is because business sustainability needs to be developed at all organizational levels, whether internal or external, and requires planning and multi-stakeholder engagement, among the most important aspects.

The proposed reframing of management structures for developing CS was achieved by grouping the elements into pillars, which made the proposal of a management structure possible, based on existing elements in the literature.

Regardless of the type of focus to be considered (whether environmental, social, or both), it is recommended the set of pillars of sustainability management presented in this paper be taken into account since they are transversal to the areas of the TBL and can support the integration of sustainability into the organizational structure.

This paper draws attention to the fact that studies in CS need not only revise but also to use the knowledge generated over the years by the academic community to further advance studies of various CS subthemes. As suggested in the title of the article, it is necessary to rethink the ways of doing business, and, for this, the development of CS in management structures has been proven to be an essentially important aspect.

The theoretical contributions are to provide researchers with some of the most important publications of the CS field, to promote the theoretical-scientific defragmentation of the literature on CS by bringing the main findings together to advance the state-of-the-art in this field, and to subsidize the development of further CS frameworks, instruments, and analyses.

This study contributes to the advancement of CS theory, using the knowledge presented in several important papers over the years. Therefore, the novelty of this proposal is to create a framework that brings together the most cited works in the CS literature and those that are already being used in companies with outstanding CS performance to support and promote the integration of sustainability in business processes.

As applied contribution, managers can consider the development of the presented pillars in companies, based on the development of the elements of CS identified. With this, they will have a management basis to support and promote the integration of sustainability in business processes. In this sense, it is argued that this study is a starting point towards structuring a management basis for supporting and promoting sustainable business development at all levels and areas of a company.

The discussion of the CS management pillars provided understanding to researchers and managers on the main aspects that make up the integration of this construct in a company from a management point of view. CS is a very comprehensive concept, and approaching it under different prisms as done in this paper is important to understand in depth the wide spectrum of elements that it is made up of.

The results of this study are limited to the literature findings of the analyzed articles and should be complemented with more practical managerial suggestions. Therefore, it is suggested that empirical analysis could discuss the proposed pillars of CS beyond the literature by checking them against the day-to-day life of companies from different industries, sizes, and countries.

In addition, due to the delimitation of the number of articles that were analyzed, it is recommended that future studies continue the study of the fundamental bases of sustainable management and add new elements to the pillars (and eventually new pillars) insofar as the state-of-the-art in CS advances. 
Author Contributions: Conceptualization, T.V.N. and O.J.d.O.; methodology, T.V.N., O.J.d.O. and M.B.; software, T.V.N.; validation, O.J.d.O. and M.B.; formal analysis, T.V.N.; investigation, T.V.N.; writing-original draft preparation, T.V.N.; writing-review and editing, T.V.N., O.J.d.O. and M.B.; supervision, O.J.d.O. and M.B.; project administration, O.J.d.O.; funding acquisition, T.V.N. and O.J.d.O. All authors have read and agreed to the published version of the manuscript.

Funding: This research was funded by the Brazilian Council for Scientific and Technological Development (CNPq), grant number PQ 312894/2017, and the São Paulo Research Foundation (FAPESP), grant numbers 2016/20160-0, 2017/18304-7 and 2019/08750-5.

Conflicts of Interest: The authors declare no conflict of interest. 


\section{Appendix A}

Table A1. Most cited articles in CS from 2007 to 2017.

\begin{tabular}{|c|c|c|c|c|}
\hline $\mathbf{N}^{\mathbf{o}}$ & Title & Author(s)/Year & Journal/ISSN & $\begin{array}{l}\text { Times Cited (Scopus } \\
\text { March 2018) }\end{array}$ \\
\hline 1 & $\begin{array}{l}\text { Corporate Social Responsibility and Corporate } \\
\text { Sustainability Separate Pasts, Common Futures }\end{array}$ & Montiel (2008) & $\begin{array}{l}\text { Organization \& } \\
\text { Environment/1086-0266 }\end{array}$ & 166 \\
\hline 2 & $\begin{array}{l}\text { Corporate Sustainability and Innovation in SMEs: } \\
\text { Evidence of Themes and Activities in Practice }\end{array}$ & Bos-Brouwers (2010) & $\begin{array}{l}\text { Business Strategy and the } \\
\text { Environment/1099-0836 }\end{array}$ & 157 \\
\hline 3 & Corporate sustainability and organizational culture & $\begin{array}{l}\text { Linnenluecke and Griffiths } \\
\text { (2010) }\end{array}$ & Journal of World Business/1090-9516 & 156 \\
\hline 4 & $\begin{array}{l}\text { Business Cases for Sustainability: The Role of Business } \\
\text { Model Innovation for Corporate Sustainability }\end{array}$ & $\begin{array}{l}\text { Schaltegger, Lüdecke-Freund } \\
\text { and Hansen (2012) }\end{array}$ & $\begin{array}{l}\text { International Journal of Innovation } \\
\text { and Sustainable } \\
\text { Development/1740-8830 }\end{array}$ & 152 \\
\hline 5 & $\begin{array}{l}\text { Corporate Sustainability Strategies: Sustainability Profiles } \\
\text { and Maturity Levels }\end{array}$ & Baumgartner and Ebner (2010) & Sustainable Development/1099-1719 & 146 \\
\hline 6 & $\begin{array}{l}\text { W(h)ither Ecology? The Triple Bottom Line, the Global } \\
\text { Reporting Initiative, and Corporate Sustainability } \\
\text { Reporting }\end{array}$ & Milne and Gray (2013) & Journal of Business Ethics/0167-4544 & 128 \\
\hline 7 & $\begin{array}{l}\text { An analysis of indicators disclosed in corporate } \\
\text { sustainability reports }\end{array}$ & Roca and Searcy (2012) & $\begin{array}{l}\text { Journal of Cleaner } \\
\text { Production/0959-6526 }\end{array}$ & 126 \\
\hline 8 & $\begin{array}{l}\text { Planetary Boundaries: Ecological Foundations for } \\
\text { Corporate Sustainability }\end{array}$ & $\begin{array}{l}\text { Whiteman, Walker and Perego } \\
\text { (2013) }\end{array}$ & $\begin{array}{l}\text { Journal of Management } \\
\text { Studies/1467-6486 }\end{array}$ & 117 \\
\hline 9 & $\begin{array}{l}\text { The Impact of Corporate Sustainability on Organizational } \\
\text { Processes and Performance }\end{array}$ & $\begin{array}{l}\text { Eccles, Ioannou and Serafeim } \\
(2014)\end{array}$ & Management Science/0025-1909 & 103 \\
\hline 10 & $\begin{array}{l}\text { Corporate Sustainability Reporting: A Study in } \\
\text { Disingenuity? }\end{array}$ & Aras and Crowther (2009) & Journal of Business Ethics/0167-4544 & 102 \\
\hline 11 & $\begin{array}{l}\text { Is Corporate Sustainability a Value Increasing Strategy for } \\
\text { Business? }\end{array}$ & Lo and Sheu (2007) & $\begin{array}{l}\text { Corporate Governance An } \\
\text { International Review/0964-8410 }\end{array}$ & 96 \\
\hline 12 & $\begin{array}{l}\text { Governance and sustainability: An investigation into the } \\
\text { relationship between corporate governance and corporate } \\
\text { sustainability }\end{array}$ & Aras and Crowther (2008) & Management Decision/0025-1747 & 93 \\
\hline
\end{tabular}


Table A1. Cont.

\begin{tabular}{|c|c|c|c|c|}
\hline $\mathbf{N}^{\mathbf{o}}$ & Title & Author(s)/Year & Journal/ISSN & $\begin{array}{l}\text { Times Cited (Scopus } \\
\text { March 2018) }\end{array}$ \\
\hline 13 & $\begin{array}{l}\text { Corporate Sustainability Performance Measurement } \\
\text { Systems:A Review and Research Agenda }\end{array}$ & Searcy (2012) & Journal of Business Ethics/0167-4544 & 91 \\
\hline 14 & $\begin{array}{l}\text { Corporate Sustainability Performance and Idiosyncratic } \\
\text { Risk: A Global Perspective }\end{array}$ & Lee (2009) & The Financial Review/1540-6288 & 89 \\
\hline 15 & The determinants of corporate sustainability performance & Artiach et al. (2010) & Accounting and Finance/1467-629X & 88 \\
\hline 16 & $\begin{array}{l}\text { The role of corporate sustainability performance for } \\
\text { economic performance: A firm-level analysis of } \\
\text { moderation effects }\end{array}$ & Wagner (2010) & Ecological Economics/0921-8009 & 79 \\
\hline 17 & $\begin{array}{l}\text { Cognitive frames in corporate sustainability: managerial } \\
\text { sensemaking with paradoxical and business case frames }\end{array}$ & Hahn et al. (2014) & $\begin{array}{l}\text { Academy of Management } \\
\text { Review/0363-7425 }\end{array}$ & 77 \\
\hline 18 & $\begin{array}{l}\text { Measuring corporate sustainability management: A data } \\
\text { envelopment analysis approach }\end{array}$ & Lee and Saen (2012) & $\begin{array}{l}\text { International Journal of Production } \\
\text { Economics/0925-5273 }\end{array}$ & 71 \\
\hline 19 & $\begin{array}{l}\text { Subcultures and Sustainability Practices: the Impact on } \\
\text { Understanding Corporate Sustainability }\end{array}$ & $\begin{array}{l}\text { Linnenluecke, Russell and } \\
\text { Griffiths (2009) }\end{array}$ & $\begin{array}{l}\text { Business Strategy and the } \\
\text { Environment }\end{array}$ & 70 \\
\hline 20 & A holistic perspective on corporate sustainability drivers & Lozano (2015) & $\begin{array}{l}\text { Corporate Social Responsibility and } \\
\text { Environmental Management }\end{array}$ & 66 \\
\hline 21 & $\begin{array}{l}\text { Defining and Measuring Corporate Sustainability: Are We } \\
\text { There Yet? }\end{array}$ & $\begin{array}{l}\text { Montiel and Delgado-Ceballos } \\
\text { (2014) }\end{array}$ & $\begin{array}{l}\text { Organization \& } \\
\text { Environment/1099-0836 }\end{array}$ & 60 \\
\hline 22 & $\begin{array}{l}\text { Tensions in Corporate Sustainability: Towards an } \\
\text { Integrative Framework }\end{array}$ & Hahn et al. (2015) & Journal of Business Ethics/0167-4544 & 57 \\
\hline 23 & $\begin{array}{l}\text { Beyond the Bounded Instrumentality in Current } \\
\text { Corporate Sustainability Research: Toward an Inclusive } \\
\text { Notion of Profitability }\end{array}$ & Hahn and Figge (2011) & Journal of Business Ethics/0167-4544 & 57 \\
\hline 24 & $\begin{array}{l}\text { Conceptualising future change in corporate sustainability } \\
\text { reporting }\end{array}$ & Adams and Whelan (2009) & $\begin{array}{l}\text { Auditing \& Accountability } \\
\text { Journal/0951-3574 }\end{array}$ & 57 \\
\hline
\end{tabular}


Table A1. Cont.

\begin{tabular}{|c|c|c|c|c|}
\hline $\mathbf{N}^{\mathbf{o}}$ & Title & Author(s)/Year & Journal/ISSN & $\begin{array}{l}\text { Times Cited (Scopus } \\
\text { March 2018) }\end{array}$ \\
\hline 25 & $\begin{array}{l}\text { What does GRI-Reporting tell us about Corporate } \\
\text { Sustainability? }\end{array}$ & Isaksson and Steimle (2009) & The TQM Journal/1754-2731 & 56 \\
\hline 26 & $\begin{array}{l}\text { The Relationship Between Sustainable Supply Chain } \\
\text { Management, Stakeholder Pressure and Corporate } \\
\text { Sustainability Performance }\end{array}$ & Wolf (2014) & Journal of Business Ethics/0167-4544 & 55 \\
\hline 27 & $\begin{array}{l}\text { Corporate sustainability: an integrative definition and } \\
\text { framework to evaluate corporate practice and guide } \\
\text { academic research }\end{array}$ & Amini and Bienstock (2014) & Journal of Cleaner Production & 54 \\
\hline 28 & $\begin{array}{l}\text { Instrumental and Integrative Logics in Business } \\
\text { Sustainability }\end{array}$ & Gao and Bansal (2013) & Journal of Business Ethics/0167-4544 & 50 \\
\hline 29 & $\begin{array}{l}\text { Corporate sustainability performance and firm } \\
\text { performance research: Literature review and future } \\
\text { research agenda }\end{array}$ & Goyal, Rahman ad Kazmi (2013) & Management Decision/0025-1747 & 49 \\
\hline 30 & $\begin{array}{l}\text { Managing Corporate Sustainability and CSR: A } \\
\text { Conceptual Framework Combining Values, Strategies and } \\
\text { Instruments Contributing to Sustainable Development }\end{array}$ & Baumgartner (2014) & $\begin{array}{l}\text { Corporate Social Responsibility and } \\
\text { Environmental } \\
\text { Management/1535-3966 }\end{array}$ & 48 \\
\hline
\end{tabular}




\section{Appendix B}

Table A2. Elements of Corporate Sustainability and their frequency of occurrence.

\begin{tabular}{|c|c|c|c|c|c|c|c|c|c|c|c|c|c|c|c|c|c|c|c|c|c|c|c|c|c|c|c|c|c|c|c|c|}
\hline \multirow{2}{*}{$\#$} & \multirow{2}{*}{ CS Elements } & \multicolumn{10}{|c|}{ Most Cited Articles \#1-10 } & \multicolumn{10}{|c|}{ Most Cited Articles \#11-20 } & \multicolumn{10}{|c|}{ Most Cited Articles \#21-30 } & \multirow{2}{*}{$\begin{array}{c}\text { Total } \\
\%\end{array}$} \\
\hline & & $\# 1$ & $\# 2$ & $\# 3$ & $\# 4$ & $\# 5$ & $\# 6$ & $\# 7$ & $\# 8$ & $\# 9$ & $\# 10$ & \#11 & $\# 12$ & $\# 13$ & $\# 14$ & $\# 15$ & $\# 16$ & $\# 17$ & $\# 18$ & $\# 19$ & $\# 20$ & $\# 21$ & $\# 22$ & $\# 23$ & $\# 24$ & $\# 25$ & $\# 26$ & $\# 27$ & $\# 28$ & $\# 29$ & $\# 30$ & \\
\hline 1 & $\begin{array}{l}\text { Cooperative relationship with } \\
\text { stakeholders }\end{array}$ & $\mathrm{x}$ & $\mathrm{x}$ & $\mathrm{x}$ & $\mathrm{x}$ & $\mathrm{x}$ & & $x$ & & $x$ & $\mathrm{x}$ & $\mathrm{x}$ & $\mathrm{x}$ & $\mathrm{x}$ & $x$ & & $x$ & & $\mathrm{x}$ & $\mathrm{x}$ & $\mathrm{x}$ & $\mathrm{x}$ & $\mathrm{x}$ & $\mathrm{x}$ & $x$ & $x$ & $x$ & $x$ & & $x$ & $x$ & $83 \%$ \\
\hline 2 & $\begin{array}{l}\text { Corporate sustainability } \\
\text { performance measurement system }\end{array}$ & $\mathrm{x}$ & & $\mathrm{x}$ & $\mathrm{x}$ & & & $\mathrm{x}$ & & $\mathrm{x}$ & $\mathrm{x}$ & $\mathrm{x}$ & $\mathrm{x}$ & $\mathrm{x}$ & $\mathrm{x}$ & $\mathrm{x}$ & $x$ & $\mathrm{x}$ & $\mathrm{x}$ & $\mathrm{x}$ & $\mathrm{x}$ & & $\mathrm{x}$ & & $\mathrm{x}$ & $\mathrm{x}$ & $\mathrm{x}$ & & $\mathrm{x}$ & $\mathrm{x}$ & & $73 \%$ \\
\hline 3 & Factory inspections and audits & $\mathrm{x}$ & $\mathrm{x}$ & $x$ & & & & $\mathrm{x}$ & & $\mathrm{x}$ & $\mathrm{x}$ & $\mathrm{x}$ & $\mathrm{x}$ & & $\mathrm{x}$ & & $\mathrm{x}$ & & $\mathrm{x}$ & $x$ & $\mathrm{x}$ & $\mathrm{x}$ & $\mathrm{x}$ & $\mathrm{x}$ & $\mathrm{x}$ & $\mathrm{x}$ & $\mathrm{x}$ & $\mathrm{x}$ & & $\mathrm{x}$ & $\mathrm{x}$ & $73 \%$ \\
\hline 4 & HR programs & $\mathrm{x}$ & $\mathrm{x}$ & & $x$ & $\mathrm{x}$ & $x$ & $\mathrm{x}$ & & $x$ & $\mathrm{x}$ & & & $\mathrm{x}$ & & & $\mathrm{x}$ & & $\mathrm{x}$ & $x$ & $x$ & $x$ & & & $\mathrm{x}$ & $x$ & $x$ & $\mathrm{x}$ & & $\mathrm{x}$ & $x$ & $67 \%$ \\
\hline 5 & Top management support & $\mathrm{x}$ & $\mathrm{x}$ & $\mathrm{x}$ & & $\mathrm{x}$ & & & & & $\mathrm{x}$ & & & & & & & $\mathrm{x}$ & $\mathrm{x}$ & $\mathrm{x}$ & & $x$ & $\mathrm{x}$ & $\mathrm{x}$ & & $\mathrm{x}$ & $\mathrm{x}$ & $\mathrm{x}$ & $\mathrm{x}$ & $\mathrm{x}$ & $\mathrm{x}$ & $63 \%$ \\
\hline 6 & Eco-efficiency-oriented measures & $\mathrm{x}$ & $\mathrm{x}$ & & $\mathrm{x}$ & $\mathrm{x}$ & & $\mathrm{x}$ & $\mathrm{x}$ & & & $\mathrm{x}$ & & & & & & $\mathrm{x}$ & $\mathrm{x}$ & $\mathrm{x}$ & $\mathrm{x}$ & $\mathrm{x}$ & $\mathrm{x}$ & & $\mathrm{x}$ & $\mathrm{x}$ & $\mathrm{x}$ & $\mathrm{x}$ & & $\mathrm{x}$ & $\mathrm{x}$ & $63 \%$ \\
\hline 7 & Long-term orientation & & & $\mathrm{x}$ & $\mathrm{x}$ & $\mathrm{x}$ & & & & $\mathrm{x}$ & $\mathrm{x}$ & $\mathrm{x}$ & $\mathrm{x}$ & $\mathrm{x}$ & & & & $\mathrm{x}$ & & $\mathrm{x}$ & $\mathrm{x}$ & $x$ & $\mathrm{x}$ & & & $\mathrm{x}$ & $\mathrm{x}$ & $\mathrm{x}$ & $\mathrm{x}$ & $\mathrm{x}$ & $\mathrm{x}$ & $63 \%$ \\
\hline 8 & Corporate sustainability report & $\mathrm{x}$ & & & $\mathrm{x}$ & $\mathrm{x}$ & & $\mathrm{x}$ & & $\mathrm{x}$ & $\mathrm{x}$ & $\mathrm{x}$ & $\mathrm{x}$ & $\mathrm{x}$ & & & & $\mathrm{x}$ & $\mathrm{x}$ & & $\mathrm{x}$ & & $\mathrm{x}$ & $\mathrm{x}$ & $\mathrm{x}$ & & $\mathrm{x}$ & & & & 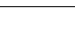 & $50 \%$ \\
\hline 9 & Risk management & $\mathrm{x}$ & $\mathrm{x}$ & & $\mathrm{x}$ & & & & & $x$ & $\mathrm{x}$ & $\mathrm{x}$ & & $\mathrm{x}$ & $\mathrm{x}$ & $\mathrm{x}$ & & & & $x$ & & $\mathrm{x}$ & & $\mathrm{x}$ & & $x$ & & $\mathrm{x}$ & & $\mathrm{x}$ & $x$ & $50 \%$ \\
\hline 10 & $\begin{array}{l}\text { Business adjustment, improvement } \\
\text { or redesign }\end{array}$ & $x$ & & $x$ & $x$ & & & & & $x$ & & & & $\mathrm{x}$ & & & $\mathrm{x}$ & & $\mathrm{x}$ & $\mathrm{x}$ & & $\mathrm{x}$ & $\mathrm{x}$ & & & $\mathrm{x}$ & & $\mathrm{x}$ & $\mathrm{x}$ & & $\mathrm{x}$ & $47 \%$ \\
\hline 11 & $\begin{array}{l}\text { Integration and balance of social, } \\
\text { environmental, and business } \\
\text { activities and responsibilities }\end{array}$ & $\mathrm{x}$ & $\mathrm{x}$ & $\mathrm{x}$ & $\mathrm{x}$ & $\mathrm{x}$ & & & & $\mathrm{x}$ & $\mathrm{x}$ & & & & & & $\mathrm{x}$ & & & & & & $\mathrm{x}$ & & & & $\mathrm{x}$ & $\mathrm{x}$ & $\mathrm{x}$ & & $\mathrm{x}$ & $43 \%$ \\
\hline 12 & $\begin{array}{l}\text { Sustainability-oriented } \\
\text { organizational culture }\end{array}$ & & & $\mathrm{x}$ & $x$ & & & & & $\mathrm{x}$ & & $\mathrm{x}$ & & & & & & & $\mathrm{x}$ & $\mathrm{x}$ & & $\mathrm{x}$ & $\mathrm{x}$ & & & & $\mathrm{x}$ & $\mathrm{x}$ & $\mathrm{x}$ & $\mathrm{x}$ & $\mathrm{x}$ & $43 \%$ \\
\hline 13 & $\begin{array}{l}\text { Product design aimed to } \\
\text { innovation on environmental } \\
\text { performance }\end{array}$ & $\mathrm{x}$ & $\mathrm{x}$ & & $\mathrm{x}$ & $\mathrm{x}$ & & $\mathrm{x}$ & & & & & & & & $\mathrm{x}$ & & $\mathrm{x}$ & & & $\mathrm{x}$ & & & & & $x$ & $\mathrm{x}$ & $\mathrm{x}$ & & $\mathrm{x}$ & $\mathrm{x}$ & $43 \%$ \\
\hline 14 & Health and safety initiatives & $\mathrm{x}$ & $\mathrm{x}$ & & & $\mathrm{x}$ & & $\mathrm{x}$ & & $\mathrm{x}$ & $\mathrm{x}$ & $\mathrm{x}$ & & & & & & & $\mathrm{x}$ & & $\mathrm{x}$ & & & & $x$ & $\mathrm{x}$ & & $\mathrm{x}$ & & & & $40 \%$ \\
\hline 15 & $\begin{array}{l}\text { Codes of conduct/corporate } \\
\text { governance/ethics }\end{array}$ & & $\mathrm{x}$ & & & $\mathrm{x}$ & & & & & $\mathrm{x}$ & $\mathrm{x}$ & & $\mathrm{x}$ & & & & & & & & & $\mathrm{x}$ & $\mathrm{x}$ & $\mathrm{x}$ & $\mathrm{x}$ & & $\mathrm{x}$ & & $\mathrm{x}$ & $\mathrm{x}$ & $40 \%$ \\
\hline 16 & Legal compliance with regulation & & & & $x$ & & & $\mathrm{x}$ & & $\mathrm{x}$ & & & & & & & & & & $x$ & $x$ & $x$ & & & $\mathrm{x}$ & $x$ & $x$ & $\mathrm{x}$ & & $\mathrm{x}$ & & $37 \%$ \\
\hline 17 & $\begin{array}{l}\text { Become an organizational changing } \\
\text { agent }\end{array}$ & $x$ & $\mathrm{x}$ & $\mathrm{x}$ & $x$ & & & $\mathrm{x}$ & & & & $\mathrm{x}$ & & & & & & & & & & & & & $\mathrm{x}$ & $\mathrm{x}$ & & $\mathrm{x}$ & & & $\mathrm{x}$ & $33 \%$ \\
\hline 18 & $\begin{array}{l}\text { Consideration of sustainability } \\
\text { issues in purchase }\end{array}$ & $\mathrm{x}$ & & & $\mathrm{x}$ & $\mathrm{x}$ & & $\mathrm{x}$ & & & & & & & & & & & & & & & $\mathrm{x}$ & & & $\mathrm{x}$ & $x$ & $\mathrm{x}$ & & & $\mathrm{x}$ & $33 \%$ \\
\hline
\end{tabular}


Table A2. Cont.

\begin{tabular}{|c|c|c|c|c|c|c|c|c|c|c|c|c|c|c|c|c|c|c|c|c|c|c|c|c|c|c|c|c|c|c|c|c|}
\hline \multirow{2}{*}{$\#$} & \multirow{2}{*}{ CS Elements } & \multicolumn{10}{|c|}{ Most Cited Articles \#1-10 } & \multicolumn{10}{|c|}{ Most Cited Articles \#11-20 } & \multicolumn{10}{|c|}{ Most Cited Articles \#21-30 } & \multirow{2}{*}{$\begin{array}{c}\text { Total } \\
\%\end{array}$} \\
\hline & & $\# 1$ & $\# 2$ & $\# 3$ & $\# 4$ & $\# 5$ & $\# 6$ & $\# 7$ & $\# 8$ & $\# 9$ & $\# 10$ & $\# 11$ & $\# 12$ & $\# 13$ & $\# 14$ & $\# 15$ & $\# 16$ & $\# 17$ & $\# 18$ & $\# 19$ & $\# 20$ & $\# 21$ & $\# 22$ & $\# 23$ & $\# 24$ & $\# 25$ & $\# 26$ & $\# 27$ & $\# 28$ & $\# 29$ & $\# 30$ & \\
\hline 19 & $\begin{array}{l}\text { Promotion of flexibility, learn and, } \\
\text { if necessary, change in processes }\end{array}$ & & $\mathrm{x}$ & $\mathrm{x}$ & $\mathrm{x}$ & & & & & & & & & & & & & & & $\mathrm{x}$ & & $\mathrm{x}$ & & & & & $\mathrm{x}$ & $\mathrm{x}$ & & $\mathrm{x}$ & $\mathrm{x}$ & $33 \%$ \\
\hline 20 & Transparency in management & & $\mathrm{x}$ & & & $\mathrm{x}$ & & & & $\mathrm{x}$ & $\mathrm{x}$ & $\mathrm{x}$ & & $\mathrm{x}$ & & & & & & & & & & $\mathrm{x}$ & & $\mathrm{x}$ & & $\mathrm{x}$ & & $\mathrm{x}$ & & $33 \%$ \\
\hline 21 & $\begin{array}{l}\text { Managerial best practices to } \\
\text { promote sustainable supply chain } \\
\text { management }\end{array}$ & & $\mathrm{x}$ & & & $\mathrm{x}$ & & & & $\mathrm{x}$ & & & & & & & $\mathrm{x}$ & & & & & & $\mathrm{x}$ & & & $\mathrm{x}$ & $\mathrm{x}$ & & & $\mathrm{x}$ & $\mathrm{x}$ & $30 \%$ \\
\hline 22 & Philanthropic responsibilities & $\mathrm{x}$ & $\mathrm{x}$ & & & & & $\mathrm{x}$ & & & $\mathrm{x}$ & $\mathrm{x}$ & & & & & $\mathrm{x}$ & & $\mathrm{x}$ & & & & & & $\mathrm{x}$ & $\mathrm{x}$ & & & & & & $30 \%$ \\
\hline 23 & $\begin{array}{l}\text { Evaluation of sustainability } \\
\text { business effect }\end{array}$ & & & & $\mathrm{x}$ & & & & & & $\mathrm{x}$ & $\mathrm{x}$ & & & $\mathrm{x}$ & $\mathrm{x}$ & & & & $\mathrm{x}$ & & & & & & $\mathrm{x}$ & $\mathrm{x}$ & & $\mathrm{x}$ & & & $30 \%$ \\
\hline 24 & Energy and water saving projects & $\mathrm{x}$ & & & & & & $\mathrm{x}$ & $\mathrm{x}$ & & & $\mathrm{x}$ & & & & & & & & & & & & & $\mathrm{x}$ & & $\mathrm{x}$ & $\mathrm{x}$ & & $\mathrm{x}$ & $\mathrm{x}$ & $27 \%$ \\
\hline 25 & $\begin{array}{l}\text { Sustainability indices and } \\
\text { guidelines }\end{array}$ & $\mathrm{x}$ & $\mathrm{x}$ & $\mathrm{x}$ & $\mathrm{x}$ & & & & & & $\mathrm{x}$ & & & $\mathrm{x}$ & & & & $\mathrm{x}$ & & & & & & & & & $\mathrm{x}$ & & & & & $27 \%$ \\
\hline 26 & Minority and diversity programs & $\mathrm{x}$ & $\mathrm{x}$ & & & & & $\mathrm{x}$ & & & $\mathrm{x}$ & & & & & & & & $\mathrm{x}$ & & $\mathrm{x}$ & & & & $\mathrm{x}$ & & & $\mathrm{x}$ & & & & $27 \%$ \\
\hline 27 & $\begin{array}{l}\text { Evaluation of company's } \\
\text { reputation and brand value }\end{array}$ & & & & $\mathrm{x}$ & & & & & & $\mathrm{x}$ & $\mathrm{x}$ & & & & & & & & $\mathrm{x}$ & $\mathrm{x}$ & & & & & $\mathrm{x}$ & & & & $\mathrm{x}$ & $\mathrm{x}$ & $27 \%$ \\
\hline 28 & $\begin{array}{l}\text { R\&D with multidisciplinary } \\
\text { innovation project teams }\end{array}$ & & $\mathrm{x}$ & $\mathrm{x}$ & $\mathrm{x}$ & $\mathrm{x}$ & & $\mathrm{x}$ & & $\mathrm{x}$ & $\mathrm{x}$ & & & & & & $\mathrm{x}$ & & $\mathrm{x}$ & & $\mathrm{x}$ & & & & & & $\mathrm{x}$ & $\mathrm{x}$ & & $\mathrm{x}$ & & $27 \%$ \\
\hline 29 & $\begin{array}{l}\text { Co-development with business } \\
\text { partners (e.g., suppliers, R\&D } \\
\text { institutions, universities) }\end{array}$ & & $\mathrm{x}$ & & $\mathrm{x}$ & $\mathrm{x}$ & & & & & & & & & & & & & & $\mathrm{x}$ & & $\mathrm{x}$ & & & & $\mathrm{x}$ & $\mathrm{x}$ & & & & $\mathrm{x}$ & $27 \%$ \\
\hline 30 & $\begin{array}{l}\text { Integration of CS with } \\
\text { management systems and/or } \\
\text { integrated management systems }\end{array}$ & & & $\mathrm{x}$ & & & & & & & & & $\mathrm{x}$ & $\mathrm{x}$ & & & & & & $\mathrm{x}$ & & & & & & & $\mathrm{x}$ & & & $\mathrm{x}$ & $\mathrm{x}$ & $23 \%$ \\
\hline 31 & $\begin{array}{l}\text { Voluntary environmental } \\
\text { restoration }\end{array}$ & $x$ & & & & $x$ & & $x$ & $x$ & & & & & & & & $x$ & & $x$ & $x$ & & & & & & & & & & & & $23 \%$ \\
\hline 32 & $\begin{array}{l}\text { Standards of corporate governance, } \\
\text { compliance, ethics }\end{array}$ & & & & & & & & & & & & & $x$ & & & & $x$ & & & & & & $x$ & $x$ & $x$ & & & & $x$ & $x$ & $23 \%$ \\
\hline 33 & $\begin{array}{l}\text { Reduction of likelihood of } \\
\text { environmental accidents }\end{array}$ & $\mathrm{x}$ & $x$ & & & $x$ & & & & & & $x$ & & & & & & & & & & & & & $x$ & & & $x$ & & & & $20 \%$ \\
\hline 34 & Employee well-being initiatives & & $\mathrm{x}$ & & & & & & & $\mathrm{x}$ & & $\mathrm{x}$ & & & & & & & & & & & & & $\mathrm{x}$ & $\mathrm{x}$ & & $\mathrm{x}$ & & & & $20 \%$ \\
\hline
\end{tabular}


Table A2. Cont.

\begin{tabular}{|c|c|c|c|c|c|c|c|c|c|c|c|c|c|c|c|c|c|c|c|c|c|c|c|c|c|c|c|c|c|c|}
\hline \multirow{2}{*}{$\#$} & \multirow{2}{*}{ CS Elements } & \multicolumn{9}{|c|}{ Most Cited Articles \#1-10 } & \multicolumn{10}{|c|}{ Most Cited Articles \#11-20 } & \multicolumn{9}{|c|}{ Most Cited Articles \#21-30 } & \multirow{2}{*}{$\begin{array}{c}\text { Total } \\
\%\end{array}$} \\
\hline & & $\# 1$ & $\# 2$ & $\# 3$ & $\# 4$ & $\# 5 \quad \# 6$ & $6 \# 7$ & $\# 8$ & $\# 9$ & $\# 10$ & $\# 11$ & $\# 12$ & $\# 13$ & $\# 14$ & $\# 15$ & $\# 16$ & $\# 17$ & $\# 18$ & $\# 19$ & $\# 20$ & $\# 21$ & $\# 22$ & $\# 23$ & $\# 24$ & $\# 25$ & $\# 26$ & $\# 27 \quad \# 28$ & $\# 29$ & $\# 30$ & \\
\hline 35 & $\begin{array}{l}\text { Environmentally and socially } \\
\text { superior products and services }\end{array}$ & & & & $\mathrm{x}$ & & & & & & & & & $\mathrm{x}$ & & & $\mathrm{x}$ & & & & & & & & $\mathrm{x}$ & $\mathrm{x}$ & & & $\mathrm{x}$ & $20 \%$ \\
\hline 36 & $\begin{array}{l}\text { Multidisciplinary innovation } \\
\text { meetings }\end{array}$ & & $\mathrm{x}$ & & $\mathrm{x}$ & & & & & & & & & & & & & & & & $\mathrm{x}$ & & & & & $\mathrm{x}$ & $\mathrm{x}$ & & $\mathrm{x}$ & $20 \%$ \\
\hline 37 & $\begin{array}{l}\text { Innovation discussion panel with } \\
\text { customers }\end{array}$ & & $\mathrm{x}$ & & $\mathrm{x}$ & & & & & & & & & & & & & & & & $\mathrm{x}$ & & & & & $\mathrm{x}$ & & $\mathrm{x}$ & $\mathrm{x}$ & $20 \%$ \\
\hline 38 & $\begin{array}{l}\text { Strategic partnerships to overcome } \\
\text { market barriers and promote new } \\
\text { products and services }\end{array}$ & & & & $\mathrm{x}$ & & & & $\mathrm{x}$ & & & & & & & & & & & & & & $\mathrm{x}$ & $\mathrm{x}$ & $\mathrm{x}$ & & $\mathrm{x}$ & & & $20 \%$ \\
\hline 39 & Fluid information exchange & & $\mathrm{x}$ & & & & & & & & & & & & & & & & & & $\mathrm{x}$ & & & & $\mathrm{x}$ & $x$ & & $\mathrm{x}$ & $\mathrm{x}$ & $20 \%$ \\
\hline 40 & $\begin{array}{l}\text { Publicate a corporate sustainability } \\
\text { policy }\end{array}$ & $\mathrm{x}$ & & $\mathrm{x}$ & & & & & & & & & & & & & & $\mathrm{x}$ & & & & & & & $\mathrm{x}$ & $\mathrm{x}$ & & $\mathrm{x}$ & & $20 \%$ \\
\hline 41 & $\begin{array}{l}\text { Reduction of operations in } \\
\text { environmentally sensitive locations }\end{array}$ & $\mathrm{x}$ & & & & $\mathrm{x}$ & & & & & $\mathrm{x}$ & & & & & & & & & & & $\mathrm{x}$ & & & & & $\mathrm{x}$ & & & $17 \%$ \\
\hline 42 & $\begin{array}{l}\text { Handling of toxic waste, effluents, } \\
\text { used products from customers, } \\
\text { plastic residues, paper and others }\end{array}$ & $\mathrm{x}$ & $\mathrm{x}$ & & & & & & & & $\mathrm{x}$ & & & & & & & & & & & & & & & $\mathrm{x}$ & $\mathrm{x}$ & $\mathrm{x}$ & $\mathrm{x}$ & $17 \%$ \\
\hline 43 & $\begin{array}{l}\text { Development of employee } \\
\text { eco-initiatives }\end{array}$ & $\mathrm{x}$ & & & & & & & & & & & & & & & & $\mathrm{x}$ & & & $\mathrm{x}$ & & & & & & $\mathrm{x}$ & $\mathrm{x}$ & & $17 \%$ \\
\hline 44 & $\begin{array}{l}\text { Occupational Health and Safety } \\
\text { and Human Rights standards }\end{array}$ & & & & & & & & & $\mathrm{x}$ & & & $\mathrm{x}$ & & & & & & & $\mathrm{x}$ & & & & & $\mathrm{x}$ & & $\mathrm{x}$ & & & $17 \%$ \\
\hline 45 & $\begin{array}{l}\text { Products and services with lower } \\
\text { energy or maintenance costs for } \\
\text { customers }\end{array}$ & $\mathrm{x}$ & & & & & & & & & & & & & & & & & & $\mathrm{x}$ & & & & $\mathrm{x}$ & & $\mathrm{x}$ & & $\mathrm{x}$ & & $17 \%$ \\
\hline 46 & Stakeholders' ideals and needs & & & & & $\mathrm{x}$ & $\mathrm{x}$ & & $\mathrm{x}$ & $\mathrm{x}$ & $\mathrm{x}$ & & $\mathrm{x}$ & & & & & & & & & & $\mathrm{x}$ & & $\mathrm{x}$ & & & & & $17 \%$ \\
\hline 47 & $\begin{array}{l}\text { Teamwork and employee } \\
\text { empowerment }\end{array}$ & & & $\mathrm{x}$ & & & & & & & & & & & & $\mathrm{x}$ & & & & & $\mathrm{x}$ & & & & & & $\mathrm{x}$ & & & $13 \%$ \\
\hline 48 & $\begin{array}{l}\text { Planning market entry or } \\
\text { development }\end{array}$ & & & & $\mathrm{x}$ & $\mathrm{x}$ & & & & & & & & & & & & & & & & & & & & & & $\mathrm{x}$ & $\mathrm{x}$ & $13 \%$ \\
\hline 49 & $\begin{array}{l}\text { Use of waste for revenue and } \\
\text { re-usable packages to delivery } \\
\text { materials }\end{array}$ & & & & $\mathrm{x}$ & & & & & & & & & & & & & & & $\mathrm{x}$ & & & & & & & & $\mathrm{x}$ & $\mathrm{x}$ & $13 \%$ \\
\hline 50 & Process improvements & & $\mathrm{x}$ & & & $\mathrm{x}$ & & & & & & & & & & & & & $\mathrm{x}$ & & & & & & & $\mathrm{x}$ & & & & $13 \%$ \\
\hline
\end{tabular}


Table A2. Cont.

\begin{tabular}{|c|c|c|c|c|c|c|c|c|c|c|c|c|c|c|c|c|c|c|c|c|c|c|c|c|c|c|c|c|c|}
\hline \multirow{2}{*}{$\#$} & \multirow{2}{*}{ CS Elements } & \multicolumn{8}{|c|}{ Most Cited Articles \#1-10 } & \multicolumn{9}{|c|}{ Most Cited Articles \#11-20 } & \multicolumn{10}{|c|}{ Most Cited Articles \#21-30 } & \multirow{2}{*}{$\begin{array}{c}\text { Total } \\
\%\end{array}$} \\
\hline & & $\# 1$ & $\# 2 \quad \# 3$ & $\# 4$ & $\# 5$ & $\# 6$ & $\# 7 \#$ & $\# 8 \quad \# 9$ & $\# 10$ & $\# 11 \quad \# 12$ & $\# 13$ & $\# 14$ & $\# 15$ & $\# 16$ & $\# 17$ & $\# 18$; & $\# 19$ & $\# 20$ & $\# 21$ & $\# 22$ & $\# 23$ & $\# 24$ & $\# 25$ & $\# 26$ & $\# 27$ & $\# 28$ & $\# 29$ & $\# 30$ & \\
\hline 51 & $\begin{array}{l}\text { Open dialogue across management } \\
\text { levels and functions }\end{array}$ & & $\mathrm{x}$ & & & & & & & & & & & & & & & & $\mathrm{x}$ & & & & & $\mathrm{x}$ & & & $\mathrm{x}$ & & $13 \%$ \\
\hline 52 & Sustainability management system & & & & & & $\mathrm{x}$ & & & & & & & $\mathrm{x}$ & & & & & & & & & & $\mathrm{x}$ & & & & & $10 \%$ \\
\hline 53 & $\begin{array}{l}\text { Geographical and marketing } \\
\text { segmentation }\end{array}$ & & & & & & & & & & & & & & & & & & & & & $\mathrm{x}$ & & & & & $\mathrm{x}$ & $\mathrm{x}$ & $10 \%$ \\
\hline 54 & $\begin{array}{l}\text { Integration of ecosystem } \\
\text { stewardship into natural resource } \\
\text { management practices }\end{array}$ & $\mathrm{x}$ & & & & & & $\mathrm{x}$ & & & & & & $\mathrm{x}$ & & & & & & & & & & & & & & & $10 \%$ \\
\hline 55 & Recruitment of local employees & & & & & & $\mathrm{x}$ & & & & & & & & & $\mathrm{x}$ & & & & & & & & & & & & $\mathrm{x}$ & $10 \%$ \\
\hline 56 & $\begin{array}{l}\text { Promotion and sponsorship of } \\
\text { projects geared toward sustainable } \\
\text { development }\end{array}$ & $\mathrm{x}$ & $\mathrm{x}$ & & & & $\mathrm{x}$ & & & & & & & & & & & & & & & & & & & & & & $10 \%$ \\
\hline 57 & $\begin{array}{l}\text { Analysis of the impact of each } \\
\text { stakeholder }\end{array}$ & & & & & & & & & $x$ & & $x$ & & & & & & & & & & & $x$ & & & & & $x$ & $10 \%$ \\
\hline 58 & $\begin{array}{l}\text { Inspiration from networks, } \\
\text { conferences }\end{array}$ & & $x$ & $\mathrm{x}$ & & & & $x$ & & & & & & & & & & & $x$ & & & & & & & & & & $10 \%$ \\
\hline 59 & Incentives and reward systems & & $x$ & & $x$ & & & $x$ & & & & & & & & & & & & & & & & & & & & & $10 \%$ \\
\hline 60 & $\begin{array}{l}\text { Ethical commitments regarding } \\
\text { 2nd and 3rd world countries }\end{array}$ & & $x$ & & & & & & & & & & & & & & & & & & $x$ & $x$ & & & & & & & $10 \%$ \\
\hline
\end{tabular}




\section{References}

1. Bocken, N.M.P.; Short, S.W.; Rana, P.; Evans, S. A literature and practice review to develop sustainable business model archetypes. J. Clean. Prod. 2014, 65, 42-56. [CrossRef]

2. Adams, R.; Jeanrenaud, S.; Bessant, J.; Denyer, D.; Overy, P. Sustainability-oriented Innovation: A Systematic Review. Int. J. Manag. Rev. 2016, 18, 180-205. [CrossRef]

3. Joyce, A.; Paquin, R.L. The triple layered business model canvas: A tool to design more sustainable business models. J. Clean. Prod. 2016, 135, 1474-1486. [CrossRef]

4. Baumgartner, R.J.; Ebner, D. Corporate Sustainability Strategies: Sustainability Profi les and Maturity Levels. Sustain. Dev. Sust. Dev. 2010, 18, 76-89. [CrossRef]

5. Milne, M.J.; Gray, R. W(h)ither Ecology? The Triple Bottom Line, the Global Reporting Initiative, and Corporate Sustainability Reporting. J. Bus. Ethics 2013, 118, 13-29. [CrossRef]

6. Holton, I.; Glass, J.; Price, A.D.F. Managing for sustainability: Findings from four company case studies in the UK precast concrete industry. J. Clean. Prod. 2010, 18, 152-160. [CrossRef]

7. Asif, M.; Searcy, C. Towards a standardised management system for corporate sustainable development. TQM J. 2014, 26, 411-430. [CrossRef]

8. Mura, M.; Longo, M.; Micheli, P.; Bolzani, D. The Evolution of Sustainability Measurement Research. Int. J. Manag. Rev. 2018, 20, 661-695. [CrossRef]

9. UNEP-FI Sustainability Metrics: Translation and Impact on Property Investment and Management. Available online: www.unepfi.org. (accessed on 1 August 2016).

10. Savino, M.M.; Mazza, A. Toward environmental and quality sustainability: An integrated approach for continuous improvement. IEEE Trans. Eng. Manag. 2014, 61, 171-181. [CrossRef]

11. United Nations Global Compact What's the Commitment? 2019. Available online: https://www. unglobalcompact.org/participation/join/commitment (accessed on 1 September 2019).

12. Roca, L.C.; Searcy, C. An analysis of indicators disclosed in corporate sustainability reports. J. Clean. Prod. 2012, 20, 103-118. [CrossRef]

13. Siew, R.Y.J. A review of corporate sustainability reporting tools (SRTs). J. Environ. Manag. 2015, 164, $180-195$. [CrossRef] [PubMed]

14. Moldavska, A.; Welo, T. The concept of sustainable manufacturing and its definitions: A content-analysis based literature review. J. Clean. Prod. 2017, 166, 744-755. [CrossRef]

15. Steurer, R.; Langer, M.E. Corporations, Stakeholders and Sustainable Development I: A Theoretical Exploration of Business - Society Relations. J. Bus. Ethics 2005, 61, 263-281. [CrossRef]

16. Adams, W.M. The Future of Sustainability: Re-thinking Environment and Development in the Twenty-first Century; Report of the IUCN Renowned Thinkers Meeting; World Conservation Union: Gland, Switzerland, 2006; Volume 29, pp. 1-18.

17. Salzmann, O.; Ionescu-Somers, A.M.; Steger, U. The business case for corporate sustainability: Literature review and research options. Eur. Manag. J. 2005, 23, 27-36. [CrossRef]

18. Gao, J.; Bansal, P. Instrumental and Integrative Logics in Business Sustainability. J. Bus. Ethics 2013, 112, 241-255. [CrossRef]

19. Lozano, R. A holistic perspective on corporate sustainability drivers. Corp. Soc. Responsib. Environ. Manag. 2015, 22, 32-44. [CrossRef]

20. Feil, A.A.; de Quevedo, D.M.; Schreiber, D. An analysis of the sustainability index of micro- and small-sized furniture industries. Clean Technol. Environ. Policy 2017, 19, 1883-1896. [CrossRef]

21. Montiel, I.; Delgado-Ceballos, J. Defining and Measuring Corporate Sustainability. Organ. Environ. 2014, 27, 113-139. [CrossRef]

22. Lloret, A. Modeling corporate sustainability strategy. J. Bus. Res. 2016, 69, 418-425. [CrossRef]

23. Hammer, J.; Pivo, G. The Triple Bottom Line and Sustainable Economic Development Theory and Practice. Econ. Dev. Q. 2017, 31, 25-36. [CrossRef]

24. Gimenez, C.; Sierra, V.; Rodon, J. Sustainable operations: Their impact on the triple bottom line. Int. J. Prod. Econ. 2012, 140, 149-159. [CrossRef]

25. Kurdve, M.; Shahbazi, S.; Wendin, M.; Bengtsson, C. Waste flow mapping to improve sustainability of waste management: A case study approach. J. Clean. Prod. 2015, 98, 304-315. [CrossRef] 
26. Gilinsky, A.; Sandra, J.; Thomas, K.N.; Cristina, S.A.; Alessio, S.; Augusti, C.; Gilinsky, A.; Sandra, J.; Thomas, K.N.; Cristina, S.A.; et al. Perceived efficacy of sustainability strategies in the US, Italian, and Spanish wine industries. Int. J. Wine Bus. Res. 2015, 3, 164-181. [CrossRef]

27. Epstein, M.J.; Roy, M.J. Sustainability in Action: Identifying and Measuring the Key Performance Drivers. Long Range Plan. 2001, 34, 585-604. [CrossRef]

28. Székely, F.; Knirsch, M. Responsible leadership and corporate social responsibility: Metrics for sustainable performance. Eur. Manag. J. 2005, 23, 628-647. [CrossRef]

29. Nawaz, W.; Koç, M. Exploring Organizational Sustainability: Themes, Functional Areas, and Best Practices. Sustainability 2019, 11, 4307. [CrossRef]

30. Gonzalez-Perez, M.A.; Leonard, L. The Global Compact: Corporate sustainability in the Post 2015 world. Adv. Sustain. Environ. Justice 2015, 17, 1-19.

31. Hahn, T.; Pinkse, J.; Preuss, L.; Figge, F. Tensions in Corporate Sustainability: Towards an Integrative Framework. J. Bus. Ethics 2015, 127, 297-316. [CrossRef]

32. Linnenluecke, M.K.; Griffiths, A. Corporate sustainability and organizational culture. J. World Bus. 2010, 45, 357-366. [CrossRef]

33. Eccles, R.G.; Ioannou, I.; Serafeim, G. The Impact of Corporate Sustainability on Organizational Processes and Performance. Manag. Sci. 2014, 60, 2835-2857. [CrossRef]

34. Hahn, R. Standardizing Social Responsibility? New Perspectives on Guidance Documents and Management System Standards for Suistanable Development. Trans. Eng. Manag. 2012, 59, 4. [CrossRef]

35. Baumgartner, R.J. Managing corporate sustainability and CSR: A conceptual framework combining values, strategies and instruments contributing to sustainable development. Corp. Soc. Responsib. Environ. Manag. 2014, 21, 258-271. [CrossRef]

36. Engert, S.; Rauter, R.; Baumgartner, R.J. Exploring the integration of corporate sustainability into strategic management: A literature review. J. Clean. Prod. 2016, 112, 2833-2850. [CrossRef]

37. Nunhes, T.V.; Bernardo, M.; Oliveira, O.J. Guiding principles of integrated management systems: Towards unifying a starting point for researchers and practitioners. J. Clean. Prod. 2018, 210, 977-993. [CrossRef]

38. Petros Sebhatu, S.; Enquist, B. ISO 14001 as a driving force for sustainable development and value creation. TQM Mag. 2007, 19, 468-482. [CrossRef]

39. Grimm, J.H.; Hofstetter, J.S.; Sarkis, J. Exploring sub-suppliers' compliance with corporate sustainability standards. J. Clean. Prod. 2016, 112, 1971-1984. [CrossRef]

40. Lozano, R.; Huisingh, D. Inter-linking issues and dimensions in sustainability reporting. J. Clean. Prod. 2011, 19, 99-107. [CrossRef]

41. Asif, M.; De Bruijn, E.J.; Fisscher, O.A.M.; Searcy, C.; Steenhuis, H.-J. Process embedded design of integrated management systems. Int. J. Qual. Reliab. Manag. 2009, 26, 261-282. [CrossRef]

42. Montiel, I. Corporate Social Responsibility and Corporate Sustainability: Separate Pasts, Common Futures. Organ. Environ. 2008, 21, 245-269.

43. van Marrewijk, M. Concepts and definitions of CSR and corporate sustainability: Between agency and communion. J. Bus. Ethics 2003, 44, 95-105. [CrossRef]

44. Bansal, P. Evolving sustainably: A longitudinal study of corporate sustainable development. Strateg. Manag. J. 2005, 26, 197-218. [CrossRef]

45. WCED Report of the World Commission on Environment and Development: Our Common Future (The Brundtland Report). Med. Confl. Surviv. 1987, 4, 300.

46. Baumgartner, R.J.; Rauter, R. Strategic perspectives of corporate sustainability management to develop a sustainable organization. J. Clean. Prod. 2017, 140, 81-92. [CrossRef]

47. Isil, O.; Hernke, M.T. The Triple Bottom Line: A Critical Review from a Transdisciplinary Perspective. Bus. Strateg. Environ. 2017, 26, 1235-1251. [CrossRef]

48. Broman, G.I.; Robèrt, K.-H. A Framework for Strategic Sustainable Development. J. Clean. Prod. 2017, 140, 1-15. [CrossRef]

49. Pádua, S.I.D.; Jabbour, C.J.C. Promotion and evolution of sustainability performance measurement systems from a perspective of business process management: From a literature review to a pentagonal proposal. Bus. Process Manag. J. 2015, 21, 403-418. [CrossRef]

50. Saratun, M. Performance management to enhance employee engagement for corporate sustainability. Asia-Pac. J. Bus. Adm. 2016, 8, 84-102. [CrossRef] 
51. Grewatsch, S.; Kleindienst, I. When Does It Pay to be Good? Moderators and Mediators in the Corporate Sustainability-Corporate Financial Performance Relationship: A Critical Review; Springer: Dordrecht, The Netherlands, 2017; Volume 145, ISBN 01674544.

52. Büyüközkan, G.; Karabulut, Y. Sustainability performance evaluation: Literature review and future directions. J. Environ. Manag. 2018, 217, 253-267. [CrossRef]

53. Kühnen, M.; Hahn, R. Systemic social performance measurement: Systematic literature review and explanations on the academic status quo from a product life-cycle perspective. J. Clean. Prod. 2018, 205, 690-705. [CrossRef]

54. Morioka, S.N.; Bolis, I.; Carvalho, M.M.D. From an ideal dream towards reality analysis: Proposing Sustainable Value Exchange Matrix (SVEM) from systematic literature review on sustainable business models and face validation. J. Clean. Prod. 2018, 178, 76-88. [CrossRef]

55. Amui, L.B.L.; Jabbour, C.J.C.; de Sousa Jabbour, A.B.L.; Kannan, D. Sustainability as a dynamic organizational capability: A systematic review and a future agenda toward a sustainable transition. J. Clean. Prod. 2017, 142, 308-322. [CrossRef]

56. De Stefano, F.; Bagdadli, S.; Camuffo, A. The HR role in corporate social responsibility and sustainability: A boundary-shifting literature review. Hum. Resour. Manag. 2018, 57, 549-566. [CrossRef]

57. Lüdeke-Freund, F.; Carroux, S.; Joyce, A.; Massa, L.; Breuer, H. The sustainable business model pattern taxonomy-45 patterns to support sustainability-oriented business model innovation. Sustain. Prod. Consum. 2018, 15, 145-162. [CrossRef]

58. Chandan, H.C. Creating alignment between corporate sustainability and Global Compact initiatives. Adv. Sustain. Environ. Justice 2015, 16, 37-59.

59. Zsóka, Á.; Vajkai, É. Corporate sustainability reporting: Scrutinising the requirements of comparability, transparency and reflection of sustainability performance. Soc. Econ. 2018, 40, 19-44. [CrossRef]

60. Goyal, P.; Rahman, Z.; Kazmi, A.A. Identification and prioritization of corporate sustainability practices using analytical hierarchy process. J. Model. Manag. 2015, 10, 23-49. [CrossRef]

61. Martinez, F. A Three-Dimensional Conceptual Framework of Corporate Water Responsibility. Organ. Environ. 2015, 28, 137-159. [CrossRef]

62. Siano, A.; Piciocchi, P.; Vollero, A.; Volpe, M.D.; Palazzo, M.; Conte, F.; De Luca, D.; Amabile, S. Developing a Framework for Measuring Effectiveness of Sustainability Communications through Corporate Websites. Procedia Manuf. 2015, 3, 3615-3620. [CrossRef]

63. Siano, A.; Conte, F.; Amabile, S.; Vollero, A.; Piciocchi, P. Communicating sustainability: An operational model for evaluating corporate websites. Sustainability 2016, 8, 950. [CrossRef]

64. Morioka, S.N.; Carvalho, M.M. Measuring sustainability in practice: Exploring the inclusion of sustainability into corporate performance systems in Brazilian case studies. J. Clean. Prod. 2016, 136, 123-133. [CrossRef]

65. Brones, F.A.; Carvalho, M.M.D.; Zancul, E.D.S. Reviews, action and learning on change management for ecodesign transition. J. Clean. Prod. 2017, 142, 8-22. [CrossRef]

66. Vildåsen, S.S.; Keitsch, M.; Fet, A.M. Clarifying the Epistemology of Corporate Sustainability. Ecol. Econ. 2017, 138, 40-46. [CrossRef]

67. Seele, P. Predictive Sustainability Control: A review assessing the potential to transfer big data driven 'predictive policing' to corporate sustainability management. J. Clean. Prod. 2017, 153, 673-686. [CrossRef]

68. Caldera, H.T.S.; Desha, C.; Dawes, L. Exploring the role of lean thinking in sustainable business practice: A systematic literature review. J. Clean. Prod. 2018, 167, 1546-1565. [CrossRef]

69. Muñoz-Torres, M.J.; Fernández-Izquierdo, M.; Rivera-Lirio, J.M.; Ferrero-Ferrero, I.; Escrig-Olmedo, E.; Gisbert-Navarro, J.V.; Marullo, M.C. An assessment tool to integrate sustainability principles into the global supply chain. Sustainability 2018, 10, 535.

70. Fritz, M.M.C.; Schöggl, J.-P.; Baumgartner, R.J. Selected sustainability aspects for supply chain data exchange: Towards a supply chain-wide sustainability assessment. J. Clean. Prod. 2017, 141, 587-607. [CrossRef]

71. Kang, S.-W.; Lee, K.-H. Mainstreaming corporate environmental strategy in management research. Benchmarking 2016, 23, 618-650. [CrossRef]

72. Yutu, W.E.; Krisnawatia, A.D.A.; Yudokoa, G.; Banguna, R. Environmental performance towards sustainable development: A review of clean production policies in Indonesia. J. Eng. Appl. Sci. 2016, 11, 1699-1705.

73. Bai, C.; Sarkis, J.; Dou, Y. Corporate sustainability development in China: Review and analysis. Ind. Manag. Data Syst. 2015, 115, 5-40. [CrossRef] 
74. El-Khalil, R.; El-Kassar, A.-N. Effects of corporate sustainability practices on performance: The case of the MENA region. Benchmarking 2018, 25, 1333-1349. [CrossRef]

75. Seuring, S.; Gold, S. Conducting content-analysis based literature reviews in supply chain management. Supply Chain Manag. Int. J. 2012, 17, 544-555. [CrossRef]

76. Bengtsson, M. How to plan and perform a qualitative study using content analysis. NursingPlus Open 2016, 2, 8-14. [CrossRef]

77. Wallace, D.P.; Van Fleet, C.; Downs, L.J. The research core of the knowledge management literature. Int. J. Inf. Manag. 2011, 31, 14-20. [CrossRef]

78. Xia, B.; Olanipekun, A.; Chen, Q.; Xie, L.; Liu, Y. Conceptualising the state of the art of corporate social responsibility (CSR) in the construction industry and its nexus to sustainable development. J. Clean. Prod. 2018, 195, 340-353. [CrossRef]

79. Aghaei Chadegani, A.; Salehi, H.; Md Yunus, M.M.; Farhadi, H.; Fooladi, M.; Farhadi, M.; Ale Ebrahim, N. A comparison between two main academic literature collections: Web of science and scopus databases. Asian Soc. Sci. 2013, 9, 18-26. [CrossRef]

80. Oliveira, O.J.; Silva, F.F.; Juliani, F.; Barbosa, L.C.F.M.; Nunhes, T.V. Bibliometric Method for Mapping the State-of-the-Art and Identifying Research Gaps and Trends in Literature: An Essential Instrument to Support the Development of Scientific Projects. In Scientometrics Recent Advances; IntechOpen: Rijeka, Croatia, 2019; p. 13. ISBN 978-1-78984-713-0.

81. Elo, S.; Kääriäinen, M.; Kanste, O.; Pölkki, T.; Utriainen, K.; Kyngäs, H. Qualitative Content Analysis: A focus in trustworthiness. SAGE Open 2014, 4,1-10. [CrossRef]

82. Scott, J. Content Analysis. In The Sage Dictionary of Social Research Methods; Sage Publications: London, UK, 2006; pp. 79-249.

83. Vaismoradi, M.; Turunen, H.; Bondas, T. Content analysis and thematic analysis: Implications for conducting a qualitative descriptive study. Nurs. Heal. Sci. 2013, 15, 398-405. [CrossRef]

84. Aras, G.; Crowther, D. Governance and sustainability. Manag. Decis. 2008, 46, 433-448. [CrossRef]

85. Miras-rodr, M.; Mart, D. Which Corporate Governance Mechanisms Drive CSR Disclosure Practices in Emerging Countries? Sustainability 2018, 11, 61. [CrossRef]

86. Bos-brouwers, H.E.J. Corporate sustainability and innovation in SMEs: Evidence of themes and activities in practice. Bus. Strateg. Environ. 2009, 19, 417-435. [CrossRef]

87. Taliento, M.; Favino, C.; Netti, A. Impact of environmental, social, and governance information on economic performance: Evidence of a corporate "sustainability advantage" from Europe. Sustainability 2019, 11, 1738. [CrossRef]

88. Wahba, H.; Elsayed, K. The mediating effect of financial performance on the relationship between social responsibility and ownership structure. Future Bus. J. 2015, 1, 1-12. [CrossRef]

89. Abatecola, G.; Cristofaro, M. Ingredients of sustainable CEO behaviour: Theory and practice. Sustainability 2019, 11, 1950. [CrossRef]

90. Ben-hassoun, A.; Aloui, C.; Ben-nasr, H. Research in International Business and Finance Demand for audit quality in newly privatized fi rms in MENA region: Role of internal corporate governance mechanisms audit. Res. Int. Bus. Financ. 2018, 45, 334-348.

91. Antolín-López, R.; Delgado-Ceballos, J.; Montiel, I. Deconstructing corporate sustainability: A comparison of different stakeholder metrics. J. Clean. Prod. 2014, 136, 5-17.

92. Adams, C.A.; Whelan, G. Conceptualising future change in corporate sustainability reporting. Account. Audit. Account. J. 2009, 22, 118-143. [CrossRef]

93. Isaksson, R.; Steimle, U. What does GRI-Reporting tell us about Corporate Sustainability? Definitions for sustainable development and sustainability. TQM J. 2009, 21, 168-181. [CrossRef]

94. Lee, K.; Farzipoor, R. Measuring corporate sustainability management: A data envelopment analysis approach. Int. J. Prod. Econ. 2012, 140, 219-226. [CrossRef]

95. Crowther, D. Corporate Sustainability Reporting: A Study in Disingenuity? Güler Aras. J. Bus. Ethics 2009, 87, 279-288.

96. Goyal, P.; Rahman, Z.; Kazmi, A.A. Corporate sustainability performance and firm performance research. Manag. Decis. 2013, 51, 361-379. [CrossRef]

97. Schaltegger, S.; Freund, F.L.; Hansen, E.G. Business cases for sustainability: The role of business model innovation for corporate sustainability. Int. J. Innov. Sustain. Dev. 2012, 6, 95. [CrossRef] 
98. Lee, D.; Faff, R. Corporate sustainability performance and idiosyncratic risk: A global perspective. Financ. Rev. 2009, 44, 213-237. [CrossRef]

99. Renwick, D.W.S.; Redman, T.; Maguire, S. Green Human Resource Management: A Review and Research Agenda*. Int. J. Manag. Rev. 2013, 15, 1-14. [CrossRef]

100. Kantabutra, S. Achieving Corporate Sustainability: Toward a Practical Theory. Sustainability 2019, 11, 4155. [CrossRef]

101. Lo, S.-F.; Sheu, H.-J. Is Corporate Sustainability a Value- Increasing Strategy for Business? Corp. Gov. Int. Rev. 2007, 15, 345-359. [CrossRef]

102. Carrion, R.D.; Fernandez, P.M.R. Developing a sustainable HRM system from a contextual perspective. Corp. Soc. Responsib. Envirionmental Manag. 2018, 25, 1143-1153.

103. Linnenluecke, M.K.; Russell, S.V.; Griffiths, A. Subcultures and sustainability practices: The impact on understanding corporate sustainability. Bus. Strateg. Environ. 2009, 18, 432-452. [CrossRef]

104. Gismera, E.; Fernández, J.L.; Labrador, J.; Gismera, L. Suffering at Work: A Challenge for Corporate Sustainability in the Spanish Context. Sustainability 2019, 11, 4152. [CrossRef]

105. Li, Y.; Tarafdar, M.; Rao, S.S. Collaborative knowledge management practices Theoretical development. Int. J. Oper. Prod. Manag. 2012, 32, 398-422. [CrossRef]

106. Zeng, J.; Anh Phan, C.; Matsui, Y.; Anh, C.; Matsui, Y. The impact of hard and soft quality management on quality and innovation performance: An empirical study. Int. J. Prod. Econ. 2014, 162, 216-226. [CrossRef]

107. Scharf, E.R.; Sierra, E.J.S. Knowledge management and the perceived value: A sustainable competitive strategy for the knowledge era. J. Inf. Syst. Technol. Manag. 2008, 5, 87-108.

108. Mahendrawathi, E.R. Knowledge management support for enterprise resource planning implementation. Procedia Comput. Sci. 2015, 72, 613-621. [CrossRef]

109. Tyagi, S.; Cai, X.; Yang, K.; Chambers, T. Lean tools and methods to support efficient knowledge creation. Int. J. Inf. Manag. 2015, 35, 204-214. [CrossRef]

110. Artiach, T.; Lee, D.; Nelson, D.; Walker, J. The determinants of corporate sustainability performance. Account. Financ. 2010, 50, 31-51. [CrossRef]

111. Searcy, C. Corporate Sustainability Performance Measurement Systems: A Review and Research Agenda. J. Bus. Ethics 2012, 107, 239-253. [CrossRef]

112. Wolf, J. The Relationship Between Sustainable Supply Chain Management, Stakeholder Pressure and Corporate Sustainability Performance. J. Bus. Ethics 2014, 119, 317-328. [CrossRef]

113. Asif, M.; Searcy, C.; Zutshi, A.; Fisscher, O.A.M. An integrated management systems approach to corporate social responsibility. J. Clean. Prod. 2013, 56, 7-17. [CrossRef]

114. Maas, K. Integrating corporate sustainability assessment, management accounting, control, and reporting. J. Clean. Prod. 2016, 136, 237-248. [CrossRef]

115. Boiral, O.; Henri, J.-F. Is Sustainability Performance Comparable? A Study of GRI Reports of Mining Organizations. Bus. Soc. 2017, 56, 283-317. [CrossRef]

116. Wasara, T.M.; Ganda, F. The Relationship between Corporate Sustainability Disclosure and Firm Financial Performance in Johannesburg Stock Exchange (JSE) Listed Mining Companies. Sustainability 2019, 11, 4496. [CrossRef]

117. Nawaz, W.; Koç, M. Development of a systematic framework for sustainability management of organizations. J. Clean. Prod. 2018, 171, 1255-1274. [CrossRef]

118. Jorgensen, T.H. Towards more sustainable management systems: Through life cycle management and integration. J. Clean. Prod. 2008, 16, 1071-1080. [CrossRef]

119. Qi, G.; Zeng, S.; Yin, H.; Lin, H. ISO and OHSAS certifications How stakeholders affect corporate decisions. Manag. Decis. 2013, 51, 1983-2005. [CrossRef]

120. Rybski, C.; Jochem, R.; Homma, L. Empirical study on status of preparation for ISO 9001:2015. Total Qual. Manag. Bus. Excell. 2017, 28, 1076-1089. [CrossRef]

121. Fonseca, L.M. Exploratory Research of ISO 14001: 2015 Transition among Portuguese Organizations. Sustainability 2018, 10, 781. [CrossRef]

122. Klute-Wenig, S.; Refflinghaus, R. Integrating sustainability aspects into an integrated management system. TQM J. 2015, 27, 303-315. [CrossRef]

123. Ranängen, H.; Cöster, M.; Isaksson, R. From Global Goals and Planetary Boundaries to Public Governance-A Framework for Prioritizing Organizational Sustainability Activities. Sustainability 2018, 10, 2741. 
124. de Oliveira Neves, F.; Salgado, E.G.; Beijo, L.A. Analysis of the Environmental Management System based on ISO 14001 on the American continent. J. Environ. Manag. 2017, 199, 251-262. [CrossRef]

125. Maletic, M.; Podpečan, M.; Maletic, D. ISO 14001 in a corporate sustainability context: A multiple case study approach. Manag. Environ. Qual. Int. J. 2015, 26, 872-890. [CrossRef]

126. Karapetrovic, S.; Casadesús, M. Implementing environmental with other standardized management systems: Scope, sequence, time and integration. J. Clean. Prod. 2009, 17, 533-540. [CrossRef]

127. Gianni, M.; Gotzamani, K.; Tsiotras, G. Multiple perspectives on integrated management systems and corporate sustainability performance. J. Clean. Prod. 2017, 168, 1297-1311. [CrossRef]

128. Witjes, S.; Vermeulen, W.J.V.; Cramer, J.M. Exploring corporate sustainability integration into business activities. Experiences from 18 small and medium sized enterprises in the Netherlands. J. Clean. Prod. 2017, 153, 528-538. [CrossRef]

129. Nunhes, T.V.; Ferreira Motta, L.C.; de Oliveira, O.J. Evolution of integrated management systems research on the Journal of Cleaner Production: Identification of contributions and gaps in the literature. J. Clean. Prod. 2016, 139, 1234-1244. [CrossRef]

130. Nunhes, T.V.; Oliveira, O.J. Analysis of Integrated Management Systems research: Identifying core themes and trends for future studies. Total Qual. Manag. 2018, 1-23. [CrossRef]

(C) 2020 by the authors. Licensee MDPI, Basel, Switzerland. This article is an open access article distributed under the terms and conditions of the Creative Commons Attribution (CC BY) license (http://creativecommons.org/licenses/by/4.0/). 